GABRIELA ARTICO

\title{
EFICÁCIA DO ÁCIDO PERACÉTICO NA DESINFECÇÃO DE INSTRUMENTOS CONTAMINADOS
}




\section{Gabriela Artico}

\section{Eficácia do ácido peracético na desinfecção de instrumentos contaminados}

Dissertação apresentada à Faculdade de Odontologia da Universidade de São Paulo, para obter o título de Mestre pelo Programa de Pós-Graduação em Odontologia.

Área de Concentração: Diagnóstico Bucal

Orientador: Prof. Dr. Jayro Guimarães Júnior

São Paulo 


\section{FOLHA DE APROVAÇÃO}

Artico G. Eficácia do ácido peracético na desinfecção de instrumentos contaminados [Dissertação de Mestrado]. São Paulo: Faculdade de Odontologia da USP; 2007.

São Paulo, / /2007.

\section{Banca Examinadora}

1) $\operatorname{Prof}(\mathrm{a}) . \operatorname{Dr}(\mathrm{a})$

Titulação:

Julgamento:

Assinatura:

2) Prof (a). Dr (a).

Titulação:

Julgamento:

Assinatura:

3) Prof (a). Dr (a).

Titulação:

Julgamento:

Assinatura: 


\section{DEDICATÓRIA}

Especialmente, para Dulce, Bete e Ana, por tudo, sem vocês nada disso teria se concretizado...

Para Alfredo (in memorian), Alzira (in memorian) e Rita (in memorian), saudades...

Para João, Silvana, Angelo e Giulia...

Para José, Icléia, Cibele e Alex, Lisandra e Marcos, Ciane e Bruno, e Lu... 


\section{DEDICATÓRIA}

À Profa. Dra. Esther Goldenberg Birman pela amizade, carinho e inspiração...

Ao Prof. Dr. Gilberto Marcucci, um exemplo a ser seguido...

À Ana Rosa Maurício, grande amiga de todas as horas...

Aos colegas da Pós-Graduação pelo companheirismo...

À Patrícia de Medeiros Loureiro Lopes e à Márcia Provenzano pela acolhida... 


\section{AGRADECIMENTOS ESPECIAIS}

Ao Prof. Dr. Jayro Guimarães Júnior pela orientação e ensinamentos de vida e à Dona Amélia pelo carinho e atenção...

À Diretora da Faculdade de Ciências Farmacêuticas da Universidade de São Paulo Dra. Terezinha de Jesus Andreoli Pinto por ter propiciado o desenvolvimento desta pesquisa e a grande oportunidade de trabalhar com sua equipe de dedicados profissionais, que, além disso, espero ter conquistado a amizade. Com certeza ficarão para sempre em minha lembrança.

À Tech Desinfecção pela doação do produto utilizado

Aos pacientes, pois sem eles nada disso seria possível.

Aos professores da Disciplina de Semiologia pela acolhida, pela presteza em me atender quando por mim interpelados, pela amizade, pela convivência e pela oportunidade do aprendizado.

À Iracema Mascarenhas Pires e Aparecida Ferreira de Andrade pela acolhida, pelo apoio e carinho: minha admiração.

Às funcionárias e colegas das outras disciplinas do Departamento de Estomatologia pela convivência amigável.

A todos os funcionários do Serviço de Documentação Odontológica pelo atendimento e disponibilidade ímpar.

Às funcionárias da Secretária de Pós-Graduação pela presteza no atendimento sempre agradável.

Ao acadêmico Felipe pelo empréstimo de seu livro.

À PROAP-CAPES pelo auxílio à pesquisa.

À CNPq pela bolsa de demanda social. 
Artico G. Eficácia do ácido peracético na desinfecção de instrumentos contaminados [Dissertação de Mestrado]. São Paulo: Faculdade de Odontologia da USP; 2007.

\section{RESUMO}

Esta pesquisa foi realizada com o objetivo de avaliar a eficácia do ácido peracético ou peroxiacético (APA) a $0,2 \%$ na desinfecção de instrumentos contaminados pela microbiota oral. Uma coleta foi realizada com instrumento termolábil usado comumente em alguns procedimentos odontológicos. A coleta foi realizada em quatro sítios da cavidade oral: mucosa jugal (lados direito e esquerdo), palato duro e dorso da língua em trinta pacientes, com quatro instrumentos diferentes para cada local. Cada um dos quatro instrumentos passou por quatro tratamentos diferentes, sendo divididos em quatro grupos: A (sem nenhum tratamento), B (tratamento com APA), $C$ (lavagem com água e detergente) e $D$ (lavagem com água e detergente e tratamento com APA). Após os tratamentos, cada instrumento foi colocado em solução salina estéril para extração dos microrganismos. Diluições da solução salina foram colocadas em placas de Petri contendo meio ágar caseína de soja ou ágar Sabouraud dextrose e incubadas de modo a favorecer, respectivamente, a anaerobiose e aerobiose ou o crescimento de bolores e leveduras. Foi realizada a contagem das unidades formadoras de colônia (UFC) e aplicados o teste ANOVA e o Teorema de Bonferroni para todas as culturas separadamente e conjuntamente para toda a microbiota oral Concluiu-se que o APA foi eficaz na desinfeç̧ão desses instrumentos.

Palavras-Chave: Ácido peracético - Desinfetantes - Desinfecção - Controle de Infecção. 
Artico G. Efficacy of peracetic acid in the disinfection of contaminated instruments [Dissertação de Mestrado]. São Paulo: Faculdade de Odontologia da USP; 2007.

\begin{abstract}
This research was realized to evaluate of the of peracetic or peroxiacetic acid (PAA), at $0,2 \%$, efficacy in the disinfection of instruments contaminated by oral microbiota. A collect was realized with heat sensitive instruments used commonly in some procedures in Dentistry in four sites of the oral cavity: buccal mucosa (left and right sides), hard palate and tongue's dorsum from thirty patients using four instruments for each site. Each instrument was treated by different methods, and was divided in four groups: A (without any treatment), B (with APA treatment), C (washed by detergent and water) and $D$ (washed by detergent and water and followed by APA treatment). After each treatment, the instruments were put in a sterile salt solution to extract the microorganism. Dilutions of this salt solution were put on Petri plaques with Tryptic soy agar or Sabouraud dextrose Agar and incubated to favor the respective anaerobiosis and aerobiosis or the growing of moulds and yeasts. The units were counted by colonies (CFU) and introduced the ANOVA test and the Theorem of Bonferroni to every separated culture and every oral microbiota. It was concluded that the APA was efficient on the disinfection of the tools instruments.
\end{abstract}

Keywords: Peracetic acid - Disinfectants - Disinfection - Infection control. 


\section{LISTA DE ILUSTRAÇÕES}

Figura 4.1 - Esquema da análise microbiológica.

55

Figura 4.2 - Identificação das placas de Petri. 56

Figura 4.3 - Contador de colônias de microrganismos 56

Figura 4.4 - Contagem das UFC 56

Gráfico 4.1 -Médias e respectivos desvios-padrão dos logaritmos das contagens de bactérias anaeróbias.

Gráfico 4.2 -Médias e respectivos desvios padrão dos logaritmos das contagens de bactérias aeróbias.

Gráfico 4.3 - Médias e respectivos desvios padrão dos logaritmos das contagens do fungos 65

Gráfico 4.4 -Médias e respectivos desvios padrão dos logaritmos das contagens do fungos.

Gráfico 5.1 -Média das contagens dos microrganismos 69 


\section{LISTA DE TABELAS}

Tabela 4.1 - Médias, desvios-padrão e erros-padrão dos logarítmos da contagem de bactérias anaeróbias

Tabela 4.2 - ANOVA realizado com os logaritmos das contagens de bactérias anaeróbias

Tabela 4.3 - Valor de $t$ para cada uma das comparações entre os grupos

Tabela 4.4 - Valor de $p$ para cada uma das comparações entre os grupos 60

Tabela 4.5 - Médias, desvios-padrão e erros-padrão dos logarítmos da contagem de bactérias aeróbias

Tabela 4.6 - Anova realizado com os logaritmos das contagens de bactérias aeróbias

Tabela 4.7 - Valor de $t$ para cada uma das comparações entre os Grupos

Tabela 4.8 - Valor de $p$ para cada uma das comparações entre os grupos

Tabela 4.9 - Médias, desvios padrão e erros padrão dos logarítmos da contagem de bolores e leveduras

Tabela 4.10 - Anova realizado com os logaritmos das contagens de fungos

Tabela 4.11 - Valor de $t$ para cada uma das comparações entre os grupos 
Tabela 4.12 - Valor de $p$ para cada uma das comparações entre os Grupos

Tabela 4.13 - Médias, desvios padrão e erros padrão dos logarítmos da contagem de microbiota oral.....

Tabela 4.14 -Anova realizado com os logaritmos das contagens da microbiota oral.

Tabela 4.15 -Valor de $t$ para cada uma das comparações entre os grupos. 66

Tabela 4.16 -Valor de $p$ para cada uma das comparações entre os grupos 


\section{LISTA DE ABREVIATURA E SIGLAS}

ADA

ANOVA

ANVISA

APA

DOU

DP

DTN

EPI

EP

FIOCRUZ

G

GL

M. tuberculosis

Mín.

$\mathrm{MI}$

OMS

Ppm

Qsp

TSA

Ref

SDA

UFC
American Dental Association

Analysis of Variance/Análise de Variância

Agência Nacional de Vigilância Sanitária

Ácido peracético

Diário Oficial da União

Desvio-padrão

Departamento Técnico Normativo

Equipamento de Proteção Individual

Erro-padrão

Fundação Oswaldo Cruz

gramas

Gay Lussac

Mycobacterium tuberculosis

mínimo

mililitros

Organização Mundial da Saúde

partes por milhão

quantidade suficiente para

Tryptic Soy Agar

Referência

Sabouraud Dextrose Agar

Unidades Formadoras de Colônias 


\section{LISTA DE SÍMBOLOS}

$\begin{array}{ll}{ }^{\circ} \mathrm{C} & \text { graus Celsius } \\ \mathrm{N}^{0} & \text { número } \\ \mathrm{SS} & \text { Radical sulfidril } \\ \mathrm{SH} & \text { Radical sulfidrila }\end{array}$




\section{SUMÁRIO}

p.

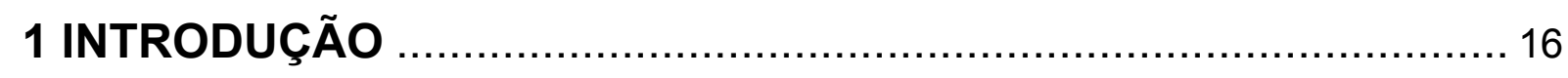

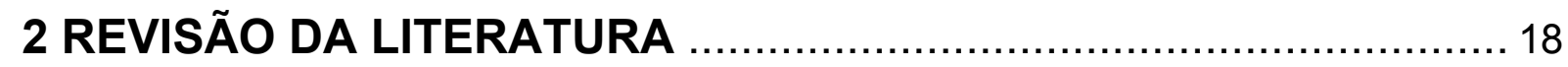

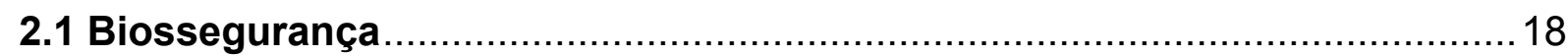

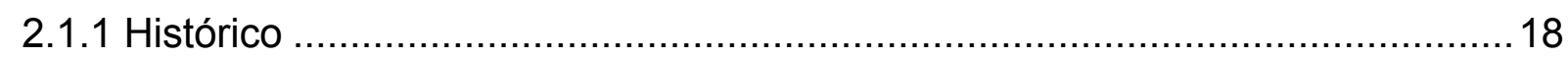

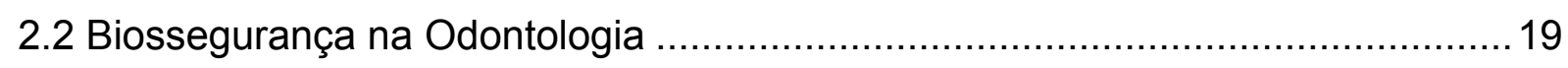

2.2.1 Riscos no consultório odontológico .................................................... 19

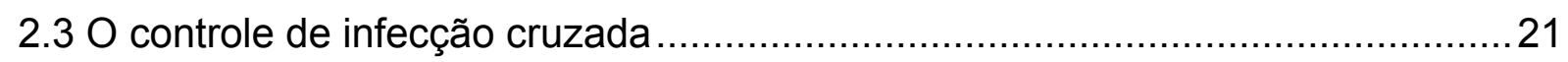

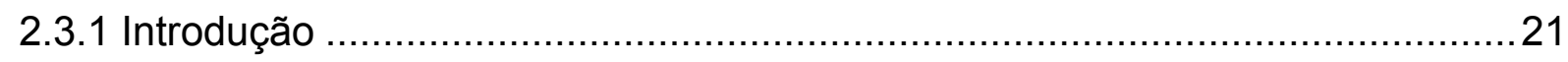

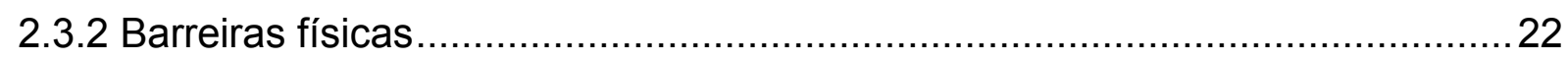

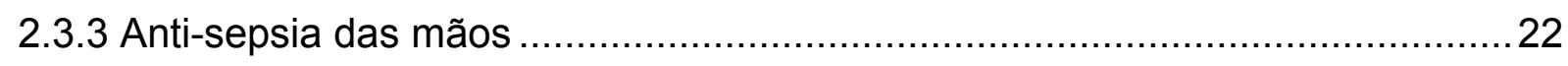

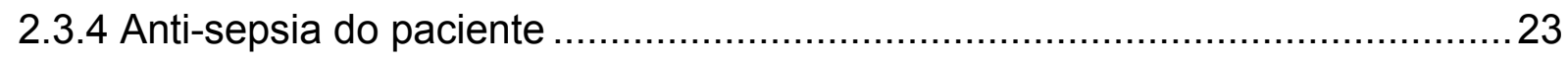

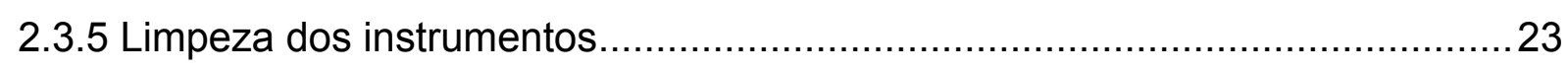

2.3.6 Classificações de Earle H. Spaulding................................................... 24

2.3.6.1 classificações dos itens, objetos e instrumentos .................................. 24

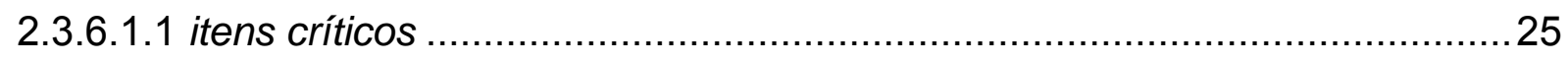

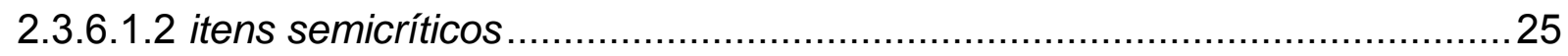

2.3.6.1.2 itens não-críticos ............................................................. 25

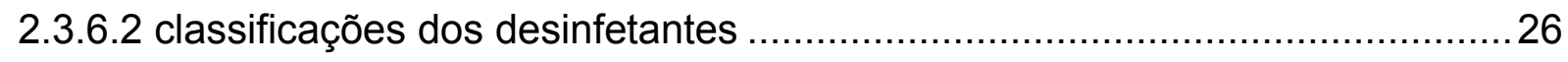

2.3.6.3.1 desinfetantes de alto nível ........................................................ 26

2.3.6.3.2 desinfetantes de nível intermediário ............................................... 26

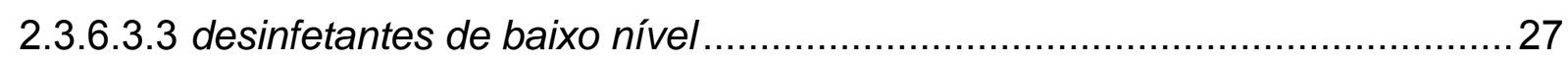

2.3.6.3 classificação de Spaulding de acordo com a resistência dos microrganismos

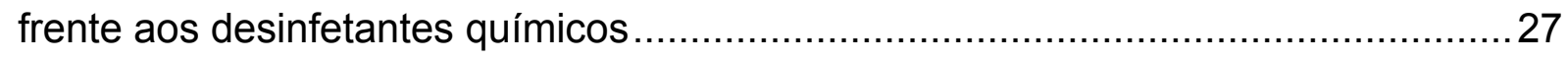

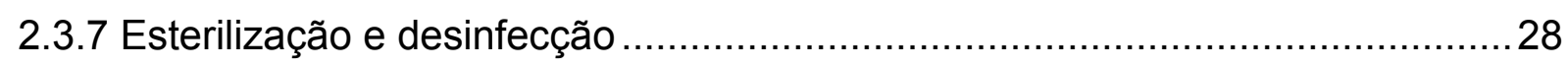

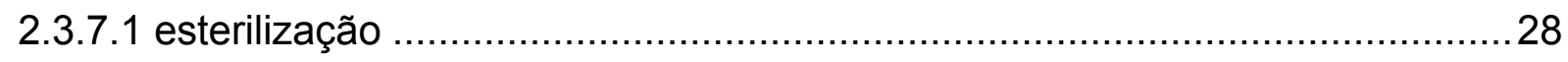

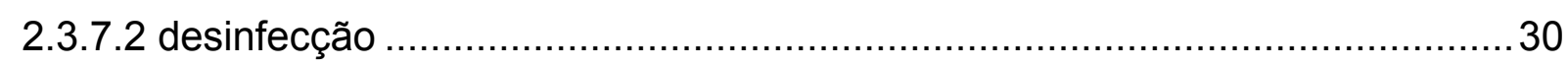


2.3.8 Outros produtos químicos para esterilização e desinfecção 31

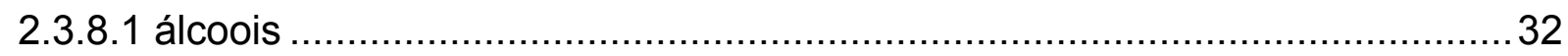

2.3.8.2 compostos quaternários de amônia …………..................................... 32

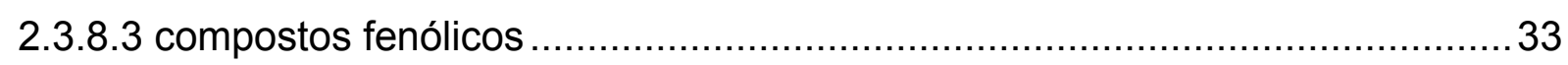

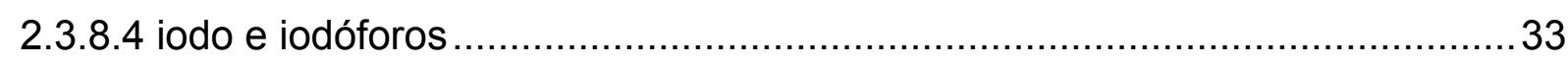

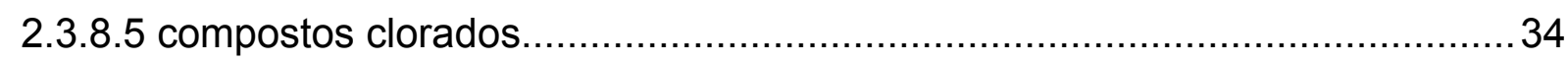

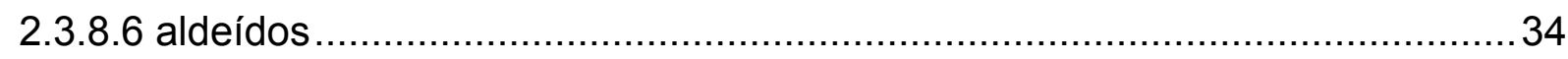

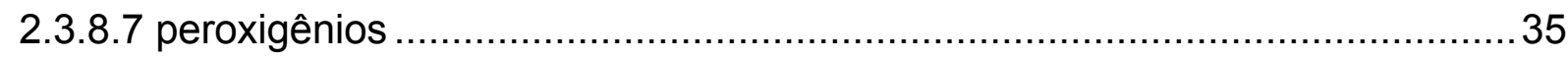

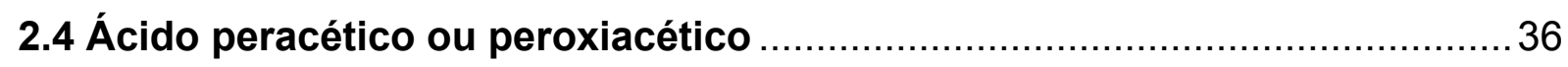

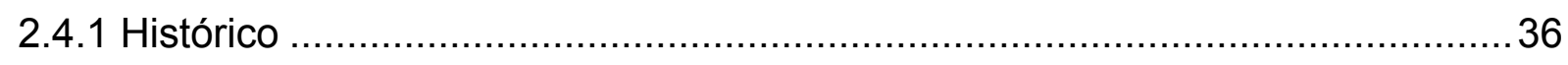

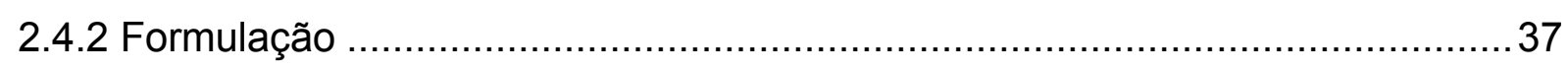

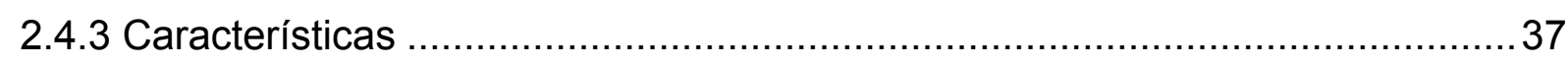

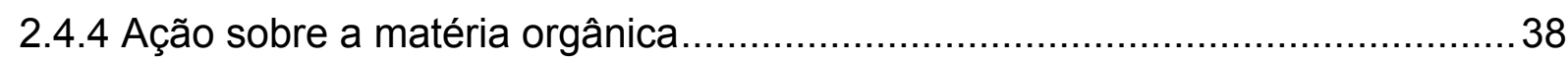

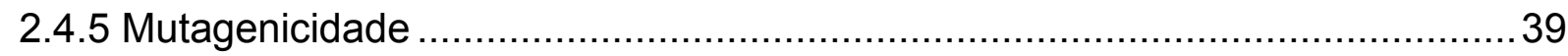

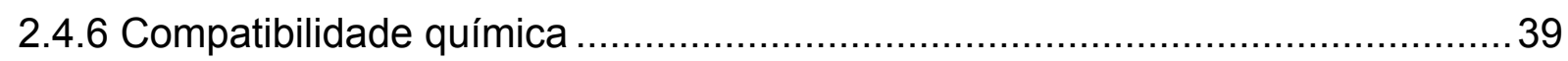

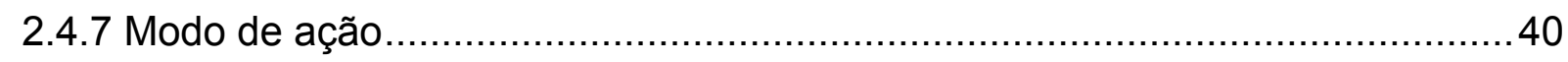

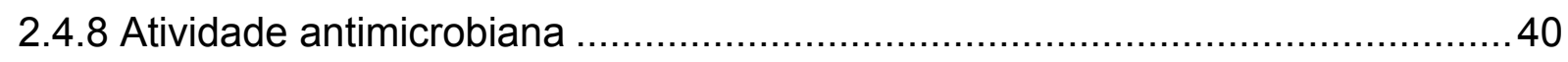

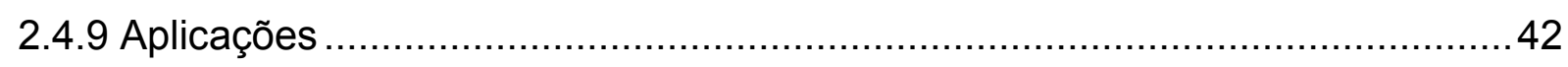

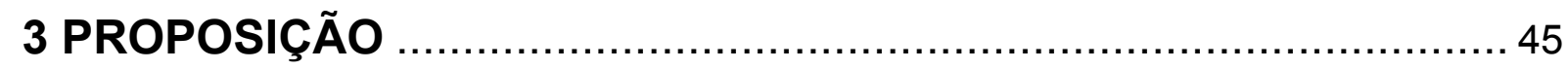

4 CASUÍSTICA, MATERIAL E MÉTODOS ..................................... 46

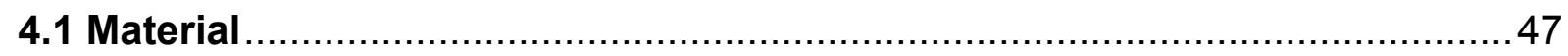

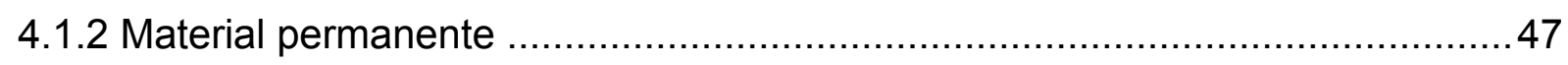

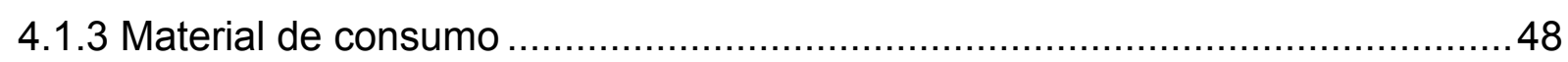

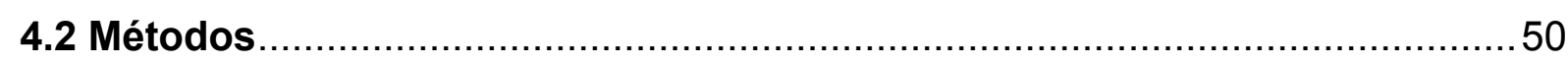

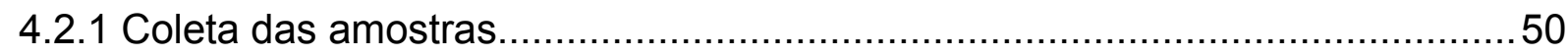

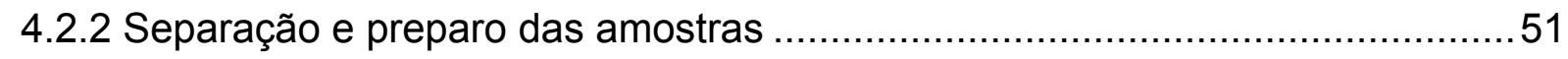

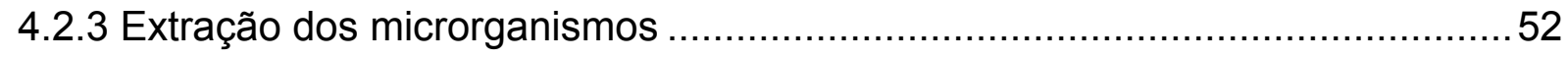

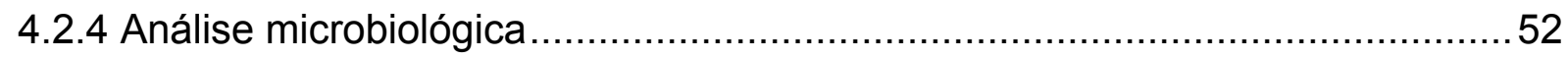

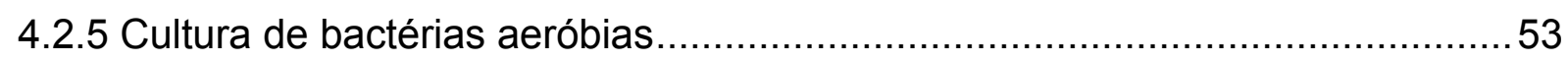

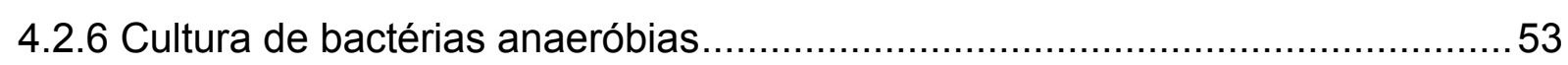

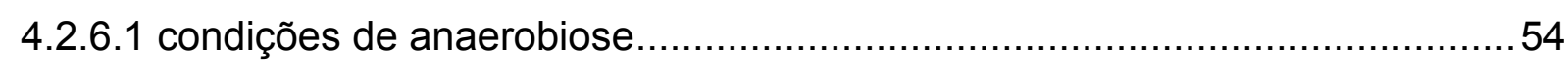

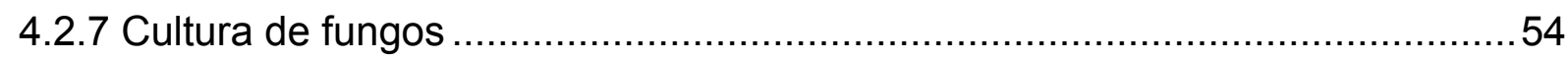

4.2.8 Contagem das unidades formadoras de colônias (UFC) .................................54 


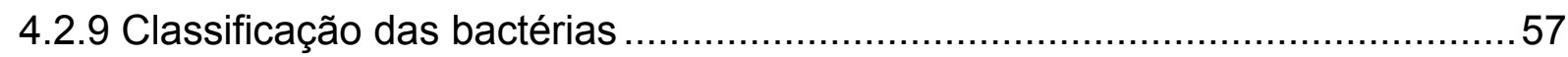

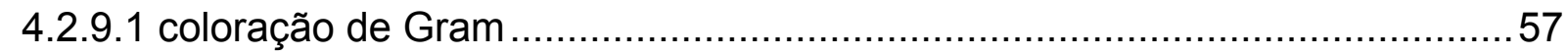

4.2.9.2 observação microscópica e classificação ..................................................58

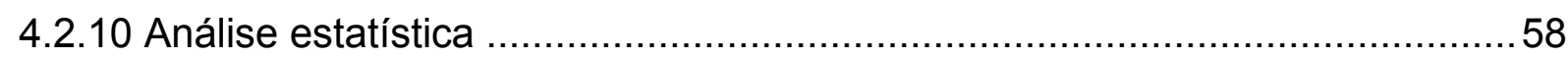

4.2.10.1 análise estatística das bactérias anaeróbias ........................................58

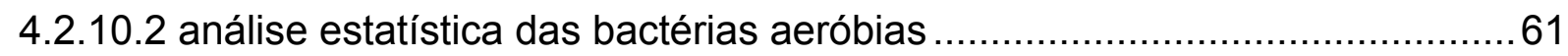

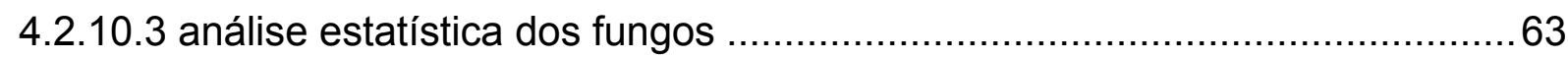

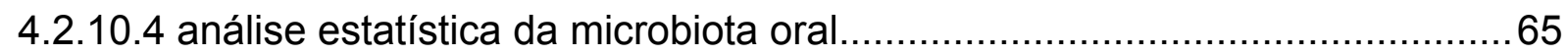

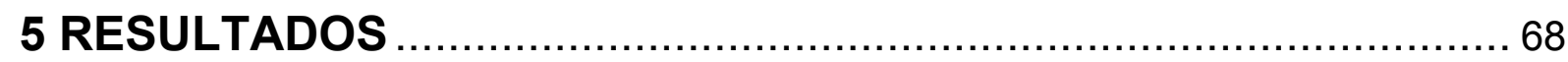

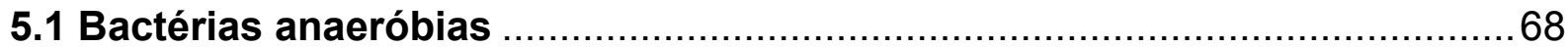

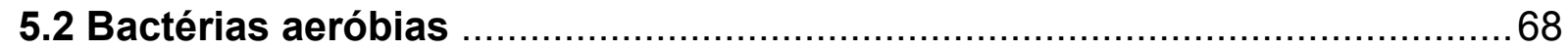

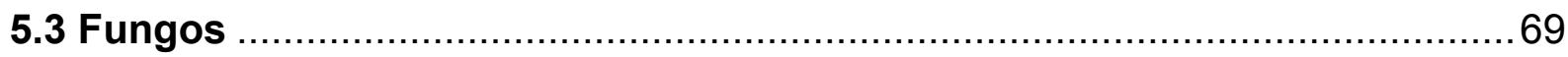

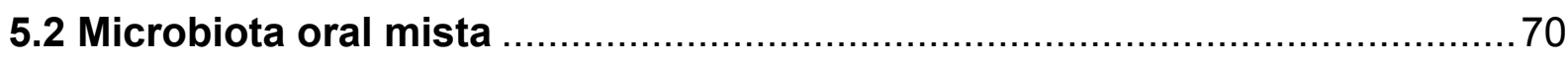

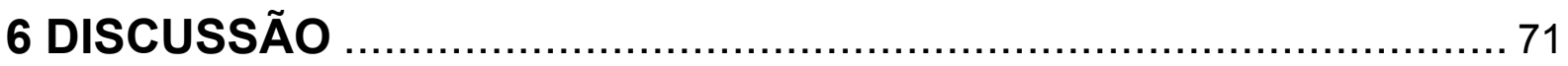

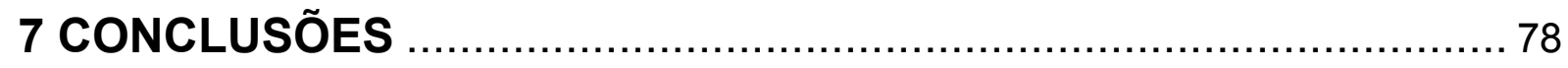

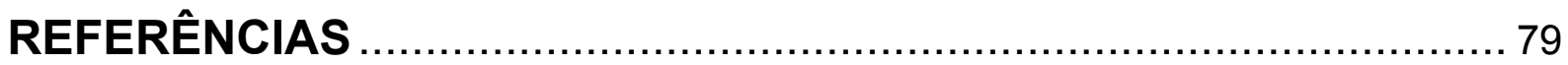

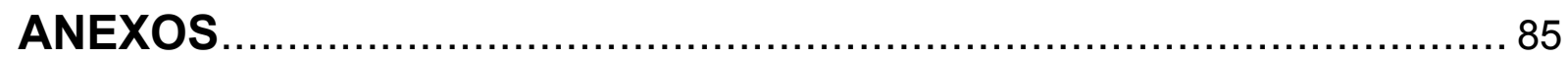




\section{INTRODUÇÃO}

A humanidade há muito vem se preocupando com a biossegurança. O Levítico bíblico cita, sob a forma de preceitos religiosos, algumas normas que podem ser consideradas como pertinentes à Biossegurança.

A biossegurança não se restringe somente aos cuidados na transmissão cruzada de doenças infecto-contagiosas em consultórios, hospitais e centros de saúde, mas também com a prevenção da aspiração de gases produzidos por substâncias químicas, injúrias causadas por produtos químicos e físicos, descarte do lixo, contaminação da água, ergonomia dos consultórios e doenças profissionais, estudo de alimentos geneticamente modificados, bioética e a legislação (GUIMARÃES JÚNIOR, 2001).

A Odontologia, a partir do século passado, mostra interesse maior com a biossegurança durante os procedimentos realizados na clínica diária, uma vez que a inquietação com o controle das infecções cruzadas tem aumentado com a descoberta de novos e diferentes microorganismos cada vez mais resistentes aos medicamentos.

Vários tipos de produtos químicos são utilizados para desinfecção e esterilização de materiais termolábeis utilizados em procedimentos das áreas da saúde, principalmente a Odontologia. Alguns deles são altamente nocivos ao profissional, aos pacientes e meio ambiente (BORGES, 2005; GUIMARÃES JÚNIOR, 2001).

Desde os anos cinqüenta, do século passado, surgiu no mercado um produto químico originado a partir da combinação de ácido acético e peróxido de hidrogênio 
chamado ácido peracético ou peroxiacético (APA). Possuindo amplo espectro de ação microbiana (BLOCK, 1991; BORGES, 2005), elimina microrganismos e seus esporos, mesmo em baixas concentrações e em contato com matéria orgânica (GRAZIANO; SILVA; BRANCHI, 2000).

O APA é classificado como ecologicamente correto, pois sua decomposição resulta na formação de água, ácido acético, oxigênio e peróxido de hidrogênio (BORGES, 2005; TORTORA; FUNKE; CASE, 2003).

Está sendo usado, por exemplo, na desinfecção de endoscópios flexíveis e outros instrumentos, na indústria de alimentos e no tratamento da água e de efluentes urbanos (KITIS, 2004; STAMPI; DE LUCCA; ZANETTI, 2001; RUTALA; WEBER, 1999), porém, na Odontologia ainda é pouco explorado, uma vez que a microbiota oral têm características particulares e é composta por numerosos e diferentes microrganismos patogênicos e não-patogênicos (JORGE, 1998) por isso é necessário um estudo a ele direcionada. 


\section{REVISÃO DE LITERATURA}

\subsection{Biossegurança}

\subsubsection{Histórico}

A preocupação com biossegurança vem desde Hipócrates (460-370 a. C), Pai da Medicina, que com sua máxima: "Primum non nocere" (Antes de tudo não prejudicar), já mencionava a responsabilidade do profissional de saúde em não causar outras doenças ao paciente por ele tratado (GUIMARÃES JÚNIOR, 2001).

Prosseguiu com Semmelweis, em 1843, que se preocupou com a morte de muitas parturientes no hospital vienense em que trabalhava, descobrindo então a necessidade da lavagem das mãos antes do trato com as pacientes. Lister, em 12 de agosto de 1865, instituiu a anti-sepsia cirúrgica, com a aplicação de ácido fênico, aspergido com vaporizadores de perfume, nas feridas pós-cirúrgicas, com grande sucesso nos seus pós-operatórios (GUIMARÃES JÚNIOR, 2001).

Com o passar das décadas o termo "Biossegurança" adquiriu um significado bastante amplo, exemplificado a seguir pelo conceito da Comissão Interna de Biossegurança da Fundação Oswaldo Cruz (FIOCRUZ):

\footnotetext{
É o conjunto de saberes direcionado para ações de prevenção, minimização ou eliminação de riscos inerentes ás atividades de pesquisa, produção, ensino, desenvolvimento tecnológico e prestação de serviços, as quais possam comprometer a saúde do homem, dos animais, das plantas e do ambiente ou a qualidade dos trabalhos desenvolvidos (FIOCRUZ, 2006).
}

A partir deste conceito pode-se afirmar então, que biossegurança não se restringe somente aos cuidados contra a transmissão cruzada de doenças infecto- 
contagiosas em consultórios, hospitais, centros de saúde, mas também com a prevenção da aspiração de gases produzidos por substâncias químicas, injúrias causadas por produtos químicos e físicos, descarte do lixo, contaminação da água, ergonomia dos consultórios e doenças profissionais, estudo de alimentos geneticamente modificados, bioética e a legislação (GUIMARÃES JÚNIOR, 2001).

O Centers for Disease Control and Prevention norte-americano, na década de 90, foi responsável pela introdução do termo "precaução universal" significando que todos os pacientes precisam ser igualmente tratados com os mesmos cuidados de biossegurança (GUIMARÃES JÚNIOR, 2001). Atualmente o mesmo conceito é chamado de precaução-padrão ou básica, pela Agência Nacional de Vigilância Sanitária (ANVISA, 2006).

No Brasil, em 19 de fevereiro de 2002, foi criada pelo Ministério da Saúde a Comissão de Biossegurança em Saúde sob direção da Secretaria de Ciência, Tecnologia e Insumos Estratégicos, com o "objetivo da implementação de ações relacionadas à Biossegurança, procurando sempre o melhor entendimento entre o Ministério da Saúde e as instituições que lidam com o tema” (SERRUYA, 2006, p.7).

\subsection{Biossegurança na Odontologia}

2.2.1 Os riscos do consultório odontológico

O conhecimento, por parte dos pacientes, da possibilidade da transmissão de doenças infecto-contagiosas no consultório odontológico reforçou, ainda mais a responsabilidade profissional e jurídica do cirurgião-dentista (GUIMARÃES JÚNIOR, 
1992). Sob a responsabilidade jurídica, o artigo 132 do Código Penal Brasileiro determina o seguinte:

Art. 132. - Expor a vida ou a saúde de outrem a perigo direto e iminente: Pena - detenção, de 3 (três) meses a 1 (um) ano, se o fato não constitui crime mais grave.

Parágrafo último. A pena é aumentada de 1/6 (um sexto) a 1/3 (um terço) se a exposição da vida ou da saúde de outrem a perigo decorre do transporte de pessoas para a prestação de serviços em estabelecimentos de qualquer natureza, em desacordo com as normas legais (BRASIL, 2007a).

Além dos vírus HIV e os da hepatite $\mathrm{B}, \mathrm{C}$ e D, existem outras doenças infectocontagiosas como a mononucleose, herpes simples I e II, a tuberculose, sífilis e gonorréia e muitas outras que podem ser transmitidas durante o tratamento dentário para os pacientes e equipe odontológica (CHASSOT; POISL; SAMUEL, 2006).

Há várias vias e formas de transmissão das doenças infecto-contagiosas. A transmissão pode se dar através do contato direto com o paciente ou suas secreções ou líquidos corpóreos, principalmente sangue ou saliva, ou, indiretamente, através de qualquer material ou instrumental odontológico contaminado, tais como os raspadores ultra-sônicos, as cadeiras odontológicas, mochos, aparelhos de raios X, interruptores de eletricidade, sugadores de saliva, flores e plantas; por próteses advindas de laboratórios, pelo aerossol e pelas gotículas de Flügge gerados que permanecem por longo tempo no ambiente, pelas linhas e condutos de água e ar que abrigam biofilmes (BERTI; MOIMAZ; AYRES, 2003; CHASSOT; POISL; SAMUEL, 2006; GUIMARÃES JÚNIOR, 2001).

O biofilme é uma película formada por várias e numerosas espécies de bactérias (ELEAZER; SCHUSTER; WEATHERS, 1997; GUIMARÃES JÚNIOR, 2001), favorecendo o crescimento de fungos e protozoários. Sendo também responsável pela nutrição, adesão e proteção das bactérias tornando-as mais resistentes a antibióticos e desinfetantes (GRAZIANO; SILVA; BIANCHI, 2000; GUIMARÃES JÚNIOR, 2001). Rautemaa et al. (2006) cita vários trabalhos 
mostrando que Pseudomonas aeruginosa, Pseudomonas cepacea, Legionella pneumophila e Mycobacterium chelonae têm sido identificadas no biofilme presente nos condutos, estrutura onde é mais difícil ou menos eficaz a ação dos desinfetantes.

\subsection{O controle de infecção cruzada}

\subsubsection{Introdução}

O controle de infecção cruzada tem por objetivo a prevenção da transmissão de doenças infecciosas da equipe odontológica para paciente, ou vice-versa e de paciente para paciente (BERTANI; FUKUNAGA; LASCALA, 2004). Além disso, deve assegurar que todos os pacientes sejam tratados com precauções universais, ou seja, através de meios de proteção eficientes usados indiscriminadamente. (GUIMARÃES JÚNIOR, 2001). As orientações são chamadas universais, uma vez que precisam ser aplicadas de maneira geral a todo paciente, independente do tipo de tratamento e de instrumento odontológicos utilizados (SCHAEFER, 1994). Os procedimentos para a minimização dos riscos de contaminação devem ser rotineiros em todo atendimento odontológico, desde um simples exame clínico até uma extensa cirurgia (BERTI; MOIMAZ; AYRES, 2003).

Os meios usados nos protocolos para controle de infecção cruzada são: o uso de equipamentos de proteção individual (EPI) (JORGE et al., 2005); e outras barreiras (ex. dique de borracha e campos cirúrgicos); degermação das mãos ou 
manilúvio com ou sem uso posterior de anti-sépticos (GUIMARÃES JUNIOR, 2001; MOLINARI, 1999; SCHEAFER, 1994); anti-sepsia oral e perioral do paciente (GUIMARÃES JUNIOR, 2001; SCHEAFER, 1994); lavagem, esterilização ou desinfecção do instrumental (GUIMARÃES JÚNIOR, 2001; RUTALA; WEBER, 2007).

\subsubsection{Barreiras físicas}

Os EPI usados são propés, óculos, gorro, avental, luvas e máscaras descartáveis (BERTI; MOIMAZ; AYRES, 2003; GUIMARÃES JÚNIOR, 2001; MOLINARI, 1999).

O dique de borracha proporciona a diminuição no espalhamento de aerossóis e também protege o paciente da aspiração de objetos estranhos durante o atendimento. As coberturas ou barreiras plásticas e os campos cirúrgicos são usadas nas mangueiras do equipo odontológico, no encosto da cadeira, sugadores, refletor, seringas tríplices, mochos e armários ou sobre o paciente ou balcões de trabalho e devem ser trocados a cada paciente (GUIMARÃES JÚNIOR, 2001).

\subsubsection{Anti-sepsia das mãos}

A Divisão de Saneantes Domissanitários do Ministério da Saúde registrou várias substâncias para a anti-sepsia das mãos, tais como: iodopovidona a 10\%, 
clorexidina a 4\%. Para a secagem das mãos devem-se tomar certos cuidados como o uso de toalhas esterilizadas para os atos cirúrgicos e para os não cirúrgicos aparelhos de ar quente (GUIMARÃES JÚNIOR, 2001).

Recentemente, se aceita o uso de álcool etílico e isopropílico para anti-sepsia das mãos, desde que não estejam visivelmente sujas e que não seja possível a degermação com detergente e água (ANVISA, 2007).

\subsubsection{Anti-sepsia do paciente}

O bochecho, pincelamento ou embrocação feitos pelo paciente com soluções anti-sépticas, como o gluconato de clorexidina a $0,12 \%$ e iodopovidona a $2 \%$, antes de qualquer procedimento odontológico (GUIMARÃES JÚNIOR, 2001; MCDONNEL; RUSSEL, 1999).

\subsubsection{Limpeza dos instrumentos}

Antes da esterilização ou desinfecção, é indispensável que os instrumentos passem por uma limpeza eficaz das sujidades e matéria orgânica (ex., sangue, saliva e secreções inflamatórias) e inorgânica (ex. materiais odontológicos) visível dos instrumentais (FARACO; MOURA, 1993), impedindo que possam interferir na eficácia destes procedimentos (RUTALA; WEBER, 2007). A pré-lavagem e lavagem 
podem ser feitas por meios manuais e/ou mecânicos (RUTALA; WEBER, 2007). As pré-lavagens são realizadas com detergentes, substâncias proteolíticas, compostos fenólicos, desencrostantes e iodóforos (BRASIL, 1994; GRAZIANO; SILVA; BIANCHI, 2000; GUIMARÃES JÚNIOR, 2001; SCHAEFER, 1994; RUTALA; WEBER, 2007).

2.3.6 Classificações de Earle H Spaulding

2.3.6.1 classificação dos itens, objetos e instrumentos

Passadas várias décadas, esta classificação é utilizada por órgãos fiscalizadores da saúde de todo o mundo e, no Brasil, foi adotada em 1994, pelo Ministério da Saúde. Os instrumentos, objetos e equipamentos usados durante o cuidado aos pacientes foram agrupados por Spaulding, de acordo com o seu contato ou não aos tecidos, observando seu nível de infecção. Os itens foram classificados em itens críticos, semicríticos e não-críticos, indicando o tipo de tratamento a que devem ser submetidos, desinfecção ou esterilização (BRASIL, 1994; GUIMARÃES JÚNIOR, 2001; RUTALA; WEBER, 2007). 
2.3.6.1.1 itens críticos

São os que tocam e penetram tecidos, exigindo o processo de esterilização (GUIMARÃES JÚNIOR, 2001). São exemplos os instrumentais cirúrgicos, periodontais e endodônticos.

\subsubsection{2 itens semicríticos}

São os que tocam os tecidos, mas não o penetram (GUIMARÃES JÚNIOR, 2001), entram em contato com membrana mucosa ou pele não íntegra (RUTALA; WEBER, 2007), necessitam desinfecção de alto nível se não puderem ser esterilizados (GUIMARÃES JÚNIOR, 2001; RUTALA; WEBER, 2007).

\subsubsection{3 itens não-críticos}

Os que não entram em contato com tecidos entram em contato com a pele, mas não com membranas mucosas (RUTALA; WEBER, 2007), necessitam passar pelo processo de desinfecção através de um desinfetante de nível intermediário e de ação tuberculicida (GUIMARÃES JÚNIOR, 2001). 
2.3.6.2 classificação dos desinfetantes

Spaulding classificou os desinfetantes de acordo com o espectro de ação frente a todos os tipos de microrganismos sendo classificando-os em diferentes níveis: alto, intermediário e baixo (GRAZIANO; SILVA; BIANCHI, 2000).

\subsubsection{1 desinfetantes de alto nível}

De acordo com Spaulding, são os capazes de inativar bactérias, fungos, vírus sob forma vegetativa ou patogênica e principalmente esporos bacterianos que apresentam maior resistência como o $M$. tuberculosis. Deve-se observar criteriosamente o tempo de imersão para que sua eficácia não seja prejudicada. (GUIMARÃES JÚNIOR, 2001) Como exemplos podem-se citar o glutaraldeído, APA e peróxido de hidrogênio (GRAZIANO; SILVA; BIANCHI, 2000).

\subsubsection{2 desinfetantes de nível intermediário}

Os desinfetantes de nível intermediário agem sob microrganismos vegetativos, fungos e vírus lipídios médios. É tuberculicida, porém não atua sob todos os tipos de esporos. São usados na desinfecção de superfícies (GRIFFITHS; 
BABB; FRAISE, 1999; GRAZIANO; SILVA; BIANCHI, 2000). Pertencem a este nível: álcool etílico e isopropílico sob fricção (70 a 90\%), fenólicos, iodóforos, hipoclorito de sódio (GRAZIANO; SILVA; BIANCHI, 2000).

\subsubsection{3 desinfetantes de baixo nível}

Os desinfetantes de baixo nível agem sob os microrganismos vegetativos, vírus lipídios médios e irregularmente sob fungos (GRIFFITHS; BABB; FRAISE, 1999). São somente usados para a desinfecção de superfícies. O álcool gel $70^{\circ} \mathrm{GL}$,

a clorexidina (JORGE et al., 2005) e o hipoclorito de sódio (FARACO; MOURA, 1993) são alguns dos desinfetantes de baixo nível.

2.3.6.3 classificação de Spaulding de acordo com a resistência dos microrganismos frente aos desinfetantes químicos

Spaulding classificou a resistência de alguns microrganismos, aos agentes químicos em ordem decrescente (BLOCK, 1991; GUIMARÃES JÚNIOR, 2001):

- esporos bacterianos,

- micobactérias,

- vírus pequenos não lipídicos,

- fungos, 
-bactérias vegetativas,

- vírus médios lipídios.

\subsubsection{Esterilização e desinfecção}

A esterilização e a desinfecção são procedimentos cruciais no controle da contaminação cruzada. Vários fatores podem influenciar a eficácia de ambos, tais como a limpeza dos instrumentos, resíduos orgânicos e inorgânicos, a natureza da contaminação microbiana e do objeto contaminado e a presença de biofilme (RUTALA; WEBER, 2007).

\subsubsection{1 esterilização}

A esterilização é o procedimento onde ocorre a destruição de todas as formas de vida microbiana ou não (GUIMARÃES JÚNIOR, 1992, 2001; MCDONNELL; RUSSELL, 1999; MOLINARI, 1999; RUTALA; WEBER, 2007; SCHAEFER, 1994), sob a forma esporulada ou não (GUIMARÃES JÚNIOR, 1992, 2001). É realizada através de métodos físicos ou químicos (GUIMARÃES JÚNIOR, 2001; MCDONNELL; RUSSELL, 1999). Para Molinari (1999) a esterilização dos instrumentos odontológicos não descartáveis é um dever irrefutável dentre as obrigações da equipe odontológica, para prevenção da contaminação cruzada. 
Os métodos físicos de esterilização são os de escolha (SCHAEFER, 1994). Utilizam o calor e dependem da temperatura e do tempo de exposição (GUIMARÃES JÚNIOR, 2001). O calor pode ser seco (estufa) ou úmido associado à pressão (autoclave) (FARACO; MOURA, 1993; GUIMARÃES JÚNIOR, 2001).

Este último é mais eficaz, penetrante e seguro que o primeiro e deve ser o método de esterilização preferido para todos os instrumentos que suportam calor. A esterilização por este método se dá através da ação do calor latente úmido liberado pelo vapor e pela pressão e conseqüente termocoagulação das proteínas e ruptura das moléculas complexas dos microrganismos (GUIMARÃES JÚNIOR, 2001).

A estufa ou forno de Pasteur utiliza o calor seco que age por oxidação sob os microrganismos. A penetrabilidade do calor seco é baixa, irregular e lenta. A eficiência da estufa é certificada quando há controle correto da temperatura e tempo de exposição. Deve ser usada para objetos que realmente não possam sofrer ação da umidade que causaria prejuízo para sua integridade, tais como pós, produtos derivados de petróleo e outros mais (FARACO; MOURA, 1993; GUIMARÃES JÚNIOR, 2001). Sabe-se que o vírus da hepatite B pode ser resistente a este meio (GRAZIANO; SILVA; BIANCHI, 2000). A Organização Mundial da Saúde (OMS) recomenda que a estufa seja usada se não houver possibilidade da utilização de qualquer outro método de esterilização, dando preferência para a autoclave (GUIMARÃES JÚNIOR, 2001) e, embora não explicitamente condenada, foi abstraída do último manual de biossegurança odontológica (ANVISA, 2007).

Guimarães Júnior (2001) comenta outros meios de esterilização: a radiação ultravioleta, que foi proibida pela Vigilância Sanitária para uso odontológico; o óxido de etileno, que é excelente, porém é bastante caro e seu processo é longo, praticamente somente usado por empresas especializadas em serviços de 
esterilização; e esterilizadores com pérolas de vidro, que são eficientes para instrumentos, endodônticos, brocas e pedras montadas.

A esterilização utilizando produtos químicos possui limitações, uma vez que precisa ser processada em meio asséptico, com água e toalhas estéreis, não podendo ser monitorada biologicamente e seu prazo de validade é curto. A efetividade de todos os desinfetantes depende de sua concentração e do tempo de imersão frente a diferentes microrganismos Existem, porém materiais que não possuem resistência a altas temperaturas (termolábeis) requerendo esterilização química (GUIMARÃES JÚNIOR, 2001).

\subsubsection{2 desinfecção}

Desinfecção é o processo que elimina os microorganismos de objetos inanimados e superfícies, com exceção de esporos bacterianos (GUIMARÃES JÚNIOR, 2001; RUTALA; WEBER, 2007; SCHAEFER, 1994) e príons (RUTALA; WEBER, 2001). Pode ser afetada pelo tempo de exposição e concentração do produto químico, a temperatura e $\mathrm{opH}$ do meio e a remoção das sujidades do material (RUTALA, 1996).

A desinfecção é classificada em três níveis: alto, intermediário e baixo (GUIMARÃES JÚNIOR, 2001). O nível alto de desinfecção é difícil de obter, pois destrói todos os vírus, bactérias vegetativas e alguns esporos fúngicos e bacterianos e inativa o resistente Mycobacterium tuberculosis (M. tuberculosis) (GUIMARÃES JÚNIOR, 2001). O nível intermediário de desinfecção elimina todas as bactérias patogênicas vegetativas, inclusive $M$. tuberculosis, mas nem todos os vírus e a 
remoção dos esporos é feita em menor quantidade (GUIMARÃES JÚNIOR, 2001). A (GRAZIANO; SILVA; BIANCHI, 2000). O nível baixo de desinfecção destrói a maioria das bactérias patogênicas. Os esporos apresentam maior resistência a um desinfetante deste nível (GUIMARÃES JÚNIOR, 2001).

Um produto químico ideal deve possuir amplo espectro de ação, devendo ser viruscida, bactericida, tuberculicida, fungicida e esporicida, altamente eficaz, solúvel em água, inodoro, econômico, atóxico para os usuários tanto em forma líquida ou em vapor, de uso fácil, boa durabilidade e estabilidade em concentração original ou diluído e não ser poluente ao meio ambiente. Precisa agir rapidamente, ter efeito residual e poder ser usado tanto como esterilizante, como desinfetante. Não deve ser inativado por sabão, detergente, fluído ou matéria orgânica; nem ser corrosivo ou causar danos aos objetos ou alterado por fatores físicos (GUIMARÃES JÚNIOR, 2001; RUTALA; WEBER, 2007).

Além de conhecer a classificação de Spaulding, o cirurgião-dentista deve conhecer os requisitos expedidos pela Portaria $n^{\circ} 15$, de 23 de agosto de 1988 do Ministério da Saúde para seleção dos produtos químicos (GRAZIANO; SILVA; BIANCHI, 2000).

2.3.8 Outros produtos químicos para esterilização e desinfecção

O Ministério da Saúde brasileiro, através de suas portarias e considerando o mecanismo de ação e o uso específico dos produtos químicos para desinfecção de superfícies e instrumentos termolábeis, bem como, para esterilização, descreve 
vários princípios ativos, tais como: quaternários de amônia, compostos fenólicos, iodados e clorados, iodóforos, e aldeídos (GRAZIANO; SILVA; BIANCHI, 2000).

\subsubsection{1 álcoois}

São eficazes contra as bactérias, vírus não-envelopados e fungos, porém, não são esporicidas. Sua ação bactericida se dá através da desnaturação de proteínas podem ser usados antes da desinfecção, para a pré-limpeza de instrumentos e superfícies (GUIMARÃES JÚNIOR, 2001; MCDONNELL; RUSSELL, 1999; TORTORA; FUNKE; CASE, 2003). Graziano, Silva e Bianchi (2000) comentam que o álcool etílico a $70 \%$ possui ação superior ao isopropílico a $92 \%$.

2.3.8.2 compostos quaternários de amônia

São agentes de superfície ou surfactantes e usados para desinfecção de baixo nível. Esses compostos agem através da inativação das enzimas, desnaturação das proteínas e ruptura as membranas celulares dos microrganismos. São eficazes contra bactérias Gram-positivas, fungos, amebas e vírus envelopados, mas não agem contra as Gram-negativas, esporos e não são tuberculicida, possuindo baixa toxicidade (GRAZIANO, SILVA; BIANCHI, 2000; MCDONNELL; RUSSELL, 1999; TORTORA; FUNKE; CASE, 2003). 
Apesar de ainda muito usado no Brasil, está condenado desde 1978 por ser um verdadeiro meio seletor de bactérias Gram-negativas, pois são ativos contra as Gram-positivas e pouco ativos contra as Gram-negativas, tais como as bactérias entéricas, Pseudomonas aeruginosa e M. tuberculosis (GUIMARÃES JÚNIOR, 2001).

2.3.8.3 compostos fenólicos

É usado para desinfecção de nível intermediário para superfícies e artigos, permanecendo ativo em presença de matéria orgânica. Sua ação se dá através do rompimento da parede celular bacteriana, da desnaturação de proteínas intracelulares e inativação de enzimas. Possuem amplo espectro de ação, porém não são esporicidas e possuem relativa toxicidade (GRAZIANO; SILVA; BIANCHI, 2000; GUIMARÃES JÚNIOR, 2001; TORTORA; FUNKE; CASE, 2003).

\subsubsection{4 iodo e iodóforos}

São usados como anti-sépticos e desinfetantes de nível intermediário (GUIMARÃES JÚNIOR, 2001).

O iodo geralmente é associado com outros agentes químicos (BRASIL, 1994). Apresenta-se sob forma de tintura, em solução de álcool aquoso (TORTORA; FUNKE; CASE, 2003). 
O iodóforo é um composto iodado vinculado a uma proteína carreadora, do qual é liberado, possuindo de penetração fácil e liberação lenta. Possuem amplo espectro de ação contra todas as bactérias, alguns esporos, nem todos os vírus e fungos (GUIMARÃES JÚNIOR, 2001; TORTORA; FUNKE; CASE, 2003).

\subsubsection{5 compostos clorados}

O cloro pode apresentar-se em forma de gás ou combinado com outros elementos químicos $\mathrm{O}$ hipoclorito de sódio é um composto recomendado para desinfecção e descontaminação de superfícies não metálicas (BRASIL, 1994). A concentração de cloro ativo que é expressa em partes por milhão (ppm), determina seu poder de desinfecção. É eficaz contra quase todos os vírus e bactérias, principalmente tuberculicida numa concentração acima de 1.000 ppm ou 0,1\% (GUIMARÃES JÚNIOR, 2001; TORTORA; FUNKE; CASE, 2003).

\subsubsection{6 aldeídos}

Fazem parte deste grupo o formaldeído e o glutaraldeído (TORTORA; FUNKE; CASE, 2003).

O formaldeído tem ação sob bactérias, fungos, vírus e também sob esporos (BRASIL, 1994) O uso deste agente atualmente não é muito recomendado pelo 
Ministério da Saúde (GUIMARÃES JÚNIOR, 2001; TORTORA; FUNKE; CASE, 2003).

O glutaraldeído é usado para desinfecção e esterilização. É especialmente usado para a desinfecção de artigos semicríticos e instrumentais termolábeis. Possui um grande espectro de ação contra bactérias, fungos vírus e esporos. Em concentração de $2 \%$ é tuberculicida. É eficaz contra o vírus da hepatite B. Devido a sua toxicidade deve ser manejado com o uso de E.P.I., pois existe a possibilidade da ocorrência de reações de hipersensibilidade na pele, olhos e vias aéreas (GUIMARÃES JÚNIOR, 2001; MCDONNELL; RUSSELL, 1999; TORTORA; FUNKE; CASE, 2003).

\subsubsection{7 peroxigênios}

O mecanismo de ação antimicrobiana destes compostos se dá pela oxidação das organelas celulares dos microrganismos $O$ peróxido de hidrogênio e o APA fazem parte deste grupo.

O peróxido de hidrogênio de acordo com relatos de 1981 pode ser usado para anti-sepsia, desinfecção e esterilização (MCDONNELL; RUSSELL, 1999). Classificado como desinfetante de alto nível ou esterilizante. Tem ação bactericida, viruscida, fungicida, micobactericida e pode ser um regular esporicida (RUTALA; WEBER, 1999). Está sendo usado em substituição ao glutaraldeído, para a desinfecção de alto nível em endoscópios (GRAZIANO; SILVA; BIANCHI, 2000). 
O APA é usado para desinfecção e esterilização (TORTORA; FUNKE; CASE 2003) e é objeto da nossa pesquisa, por isto, será detalhado separadamente.

\section{4 Ácido peracético ou peroxiacético (APA)}

\subsubsection{Histórico}

A atividade antimicrobiana do APA foi primeiramente observada em 1902 por Freer e Novy. Em 1949, Hutchings e Xezones verificaram ser mais eficiente que outros 23 germicidas testados contra esporos de Bacillus thermoacidurans. Pesquisas de Greenspan e McKellar, em 1951, comprovaram sua ação bactericida, fungicida e esporicida (BLOCK, 1991).

No Brasil, a Resolução n 2586, de 10 de agosto de 2006 alterou o item "e" da Portaria no 122/DTN, de 29 de novembro de 1993, que incluiu na Portaria $n^{\circ} 15$ de 23 de agosto de 1988, subanexo um, alínea I, o princípio ativo ácido peracético, para uso das formulações de desinfetantes/esterilizantes. Esta resolução foi publicada no Diário Oficial da União (D.O.U) - Poder Executivo, de 14 de agosto de 2006 (BRASIL, 2007b). 


\subsubsection{Formulação}

Os autores afirmam que o APA é um composto quaternário orgânico formado a partir ácido acético e água (GRAZIANO; SILVA; BIANCHI, 2000; KITIS, 2004; STAMPI; DE LUCA; ZANETTI, 2001).

$$
\begin{array}{cccc}
\mathrm{CH}_{3} \mathrm{CO}_{2} \mathrm{H}+\mathrm{H}_{2} \mathrm{O}_{2} \leftrightarrow & \mathrm{CH}_{3} \mathrm{CO}_{3}-\mathrm{H}+\mathrm{H}_{2} \mathrm{O} \\
\begin{array}{c}
\text { Ácido } \\
\text { Acético }
\end{array} & \begin{array}{c}
\text { Peróxido } \\
\text { de } \\
\text { Hidrogênio }
\end{array} & \text { Peracético } & \text { Água } \\
& &
\end{array}
$$

\subsubsection{Características}

O APA é considerado ecologicamente correto (BORGES, 2005), pois seus produtos residuais não são tóxicos. Decompõe-se em água, ácido acético, oxigênio e peróxido de hidrogênio (GRAZIANO; SILVA; BIANCHI, 2000; STAMPI; DE LUCA; ZANETTI, 2001; WAGNER; BRUMELIS; GEHR, 2002).

Possui características de um poderoso oxidante e desinfetante (KITIS, 2004; STAMPI; DE LUCA; ZANETTI, 2001). Combina a atividade do oxigênio ativo característico dos peróxidos, dentro de uma molécula de ácido acético pertencendo, à classe dos peróxidos orgânicos fabricados sinteticamente (BLOCK, 1991).

O APA é um líquido incolor, possuindo um forte odor avinagrado, com $\mathrm{pH}$ ácido menor que dois. É solúvel em água e solventes orgânicos e levemente solúvel em solventes aromáticos (KITIS, 2004). Por fazer parte da família dos peróxidos que são compostos de alto estado de energia, o APA é considerado termodinamicamente instável, porém, soluções diluídas desta solução são 
consideradas mais estáveis, precisando ser estocado em lugares com temperatura não superior a $30{ }^{\circ} \mathrm{C}$ e em sua embalagem escura própria (BLOCK, 1991).

O APA pode ser utilizado em um amplo espectro de temperaturas que vai de 0 a $40{ }^{\circ} \mathrm{C}$ e é ativo em $\mathrm{pH}$ que pode variar de 3,0 a 7,5 , não sendo afetado por resíduos protéicos (KUGNIGK; ALMEIDA, 2001).

Em meio ácido, a atividade antimicrobiana do APA é excelente e apresenta ação rápida contra esporos bacterianos e leveduras (BALDRY, 1983; BLOCK, 1991).

A eficácia do APA pode ser influenciada pelo aumento da temperatura, pelo nível de contaminação microbiana, pela quantidade de suspensões sólidas, pela demanda química de oxigênio, mas não pelo pH do meio (STAMPI; DE LUCA; ZANETTI, 2001; STAMPI et al., 2002).

\subsubsection{Ação sobre a matéria orgânica}

É ativo mesmo na presença de matéria orgânica, ou seja, em contato com sangue, fluídos corpóreos e gordura (BLOCK, 1991; BORGES, 2005).

A ação do APA sob depósitos biológicos ou biofilmes que seria pela oxidação química em seu interior e sua habilidade de fixar ou removê-los é ainda pouco documentada. Algumas formulações de APA que não possuíam surfactantes catiônicos ocasionaram a fixação indesejável de alguns biofilmes sobre superfícies de vidro testadas (LOUKILI et al., 2004; LOUKILI et al., 2006).

Para Liberti e Notarnicola (1999) na desinfecção com o APA pode ocorrer o aumento de conteúdo orgânico nos efluentes urbanos por causa do ácido acético 
que é originado pela sua decomposição que pode ocasionar um novo crescimento microbiano.

\subsubsection{Mutagenicidade}

Os produtos isolados da decomposição do APA, após seu uso no tratamento de águas fluviais, foram predominantemente a formação de ácidos carboxílicos, não possuindo propriedades mutagênicas (MONARCA et al., 2002).

Crebelli et al. (2005) demonstram, em seu estudo, que o uso de doses moderadas de APA para a desinfecção da água do esgoto não propiciou a formação de quantia significativa de produtos genotóxicos.

Não deve ser descartada a possibilidade eventual da formação de produtos tóxicos ou mutagênicos em alguns casos (KITIS, 2004), porém, esta possibilidade da é baixa (DITOMMASO et al., 2005).

\subsubsection{Compatibilidade química}

O APA não reage quimicamente com vidro e muitos tipos de plásticos, porém, reage com algumas formulações de vinil, borrachas sintéticas e naturais, já outros autores relatam que muitos materiais são suscetíveis à corrosão como aço galvanizado, cobre, bronze e latão e os que apresentam resistência a este 
desinfetante são alumínio puro e aço inox (KITIS, 2004). Estes efeitos sobre alguns materiais podem ser minimizados com o uso de aditivos e modificação do $\mathrm{pH}$ (BLOCK, 1991).

2.4.7 Modo de ação

A atividade desinfetante do APA se dá pela liberação do oxigênio ativo (BLOCK, 1991) e radical hidroxi (CHASSOT; POISL; SAMUEL, 2006). Pela oxidação das ligações SS (sulfidril) e SH (sulfidrila), ocorre o aumento da permeabilidade da parede celular, conteúdo citoplasmático e material genético interferindo assim, nas reações químicas de sobrevivência e reprodução celular dos microrganismos (CHASSOT; POISL; SAMUEL, 2006; MCDONNEL; RUSSEL, 1999; KITIS, 2004). O APA atua diretamente nas bases da molécula de DNA que são capazes de inativar a catalase, uma enzima que pode interferir nos radicais hidroxi (BLOCK, 1991) podendo ocorrer a desnaturação de proteínas e enzimas dos microrganismos (MCDONNEL; RUSSEL, 1999).

2.4.8 Atividade antimicrobiana

O APA possui um amplo espectro de atividade antimicrobiana (BLOCK, 1991). Elimina vírus, bactérias em forma vegetativa e esporulada, fungos e 
protozoários (LIBERT; NOTARNICOLA, 1999). Seu tempo de atuação é de dez minutos para desinfecção de alto grau e de uma hora para esterilização, tempo bem menor que o de outras substâncias, entre elas, o glutaraldeído (BORGES, 2005).

De acordo com Wutzel e Sauerbrei (2000) o APA tem ação viruscida, que pode ser aumentada, quando é associado ao etanol a $80 \%$ observa-se a inativação dos vírus em menor tempo.

O APA é esporicida mesmo em baixas concentrações de $0,0001 \%$ a $0,2 \%$. (BLOCK, 1991), demonstra a ação bactericida e fungicida com cinco minutos de imersão e concentrações de até 100 ppm sem a presença de matéria orgânica e de 200 a 500 ppm com presença desta. (GRAZIANO; SILVA; BIANCHI, 2000). Em 0,003\% tem ação como fungicida (KITIS, 2004).

Possui a capacidade de inativar bactérias Gram-positivas e Gram-negativas, (BLOCK, 1991; CHASSOT, POISL; SAMUEL, 2006), fungos e leveduras em poucos minutos (BLOCK, 1991). Para Vizcaino-Alcaide, Herruzo-Cabrera e FernandezAceñero (2003) se fez necessário um maior tempo de contato para ter ação efetiva contra leveduras.

É um eficiente agente micobactericida, sendo bastante eficiente contra $M$. tuberculosis, necessita tempo maior de contato em objetos contaminados pelo Mycobacterium avium-intracellulare e age rapidamente sob o Mycobacterdium chelonae (MIDDLETON; CHADWICK; GAYA, 1997), este último, já apresentou resistência ao glutaraldeído (BORGES, 2005).

É efetivo também na inativação de protozoários e patógenos ciliados (STAMPI; DE LUCA; ZANETTI, 2001).

O APA mostrou-se eficiente na erradicação de Legionella pneumophila (DITOMMASO et al., 2005; LEONI et al., 2006). Mostrou ação bactericida rápida 
contra Staphylococcus aureus e Pseudomonas aeruginosa (LAMBERT; JOHNSTON; SIMONS, 1999).

De acordo com o estudo de Chassot, Poisl e Samuel (2006) o APA proporcionou esterilização, eliminando esporos das cepas Bacillus subtilis e Bacillus stearothermophilus em artigos semicríticos odontológicos, estas são duas bactérias que estão sendo usadas para controle de esterilidade por serem resistentes a altas temperaturas.

Angelillo et al. (1998) observaram a desinfecção de instrumentos odontológicos, com a inativação de bactérias vegetativas em 15 minutos, porém, a atividade contra esporos de Bacillus subtilis necessitou maior tempo de imersão dos instrumentos dentais, quando foi utilizado um desinfetante a base de peroxigênio.

\subsubsection{Aplicações}

Apesar de seu elevado custo, devido a sua capacidade de produção limitada no mundo inteiro, o APA está sendo utilizado e pesquisado em vários setores tais como ambientais e industriais (KITIS, 2004).

O APA é usado como desinfetante para tratamento de água de esgoto (KITIS, 2004), podendo, ser usado em combinação com raio ultravioleta (RAJALAMUSTONEN et al., 1997), também, Koivunem e Heinonen (2005) demonstraram que o APA pode ser uma alternativa para desinfecção de efluentes primário, secundário e terciário de esgotos. 
É utilizado como desinfetante e esterilizante em muitas indústrias como as de processamento de alimentos, bebidas, médicas, farmacêuticas. Também usado com agente descolorante em indústria têxtil, de papel e polpa (KITIS, 2004).

$\mathrm{Na}$ indústria farmacêutica atua como agente esterilizante de emulsões, pomadas e talcos. O APA sob forma de aerossol serve para esterilização de salas estéreis e manutenção de animais gnotobióticos (BLOCK, 1991).

É usado para a esterilização e desinfecção de equipamentos e instrumentos termossensíveis para uso médico e hospitalar (CHASSOT; POISL; SAMUEL, 2006) como broncoscópios (MIDDLETON; CHADWICK; GAYA, 1997), aparelhos para hemodiálise (LYNAM; BABB; FRAISE, 1995).

Na esterilização de endoscópios de fibras ópticas rígidas ou flexíveis e outros tipos de objetos médico-hospitalares utilizando-se equipamento automático computadorizado que possui conectores permitindo então a passagem do APA pelos canalículos dos endoscópios (GRAZIANO; SILVA; BIANCHI, 2000; RUTALA; WEBER, 1999). Este aparelho tem sido estudado em vários países como Estados Unidos, Canadá, Austrália e Europa (SATTAR et al., 2006).

Existem estudos sobre o uso do APA para desinfecção diferentes instrumentos dentários (ANGELILLO et al. 1998) e para desinfecção de alto nível em peças de resina acrílica, um material bastante utilizado na Odontologia (CHASSOT; POISL; SAMUEL, 2006). Apresentou resultados positivos no controle de contaminação microbiana e de biofilme na linha de água de unidade dentária (MONTEBUGNOLI et al., 2004).

Em investigações quanto sua utilização em protocolos para desinfecção de enxerto homólogo de tendão patelar, o APA mostrou ser efetivo, não ocorrendo alterações em termos de biocompatibilidade e biomecânica (LOMAS et al., 2004a). 
Estudo realizado para avaliar o uso de APA combinado com altas concentrações de glicerol e propilenoglicol mostrou ser eficaz no reprocessamento de pele contaminada de cadáveres para enxertos homólogos, sem causar efeitos citotóxicos, pro - inflamatórios ou inibitórios da colagenase (LOMAS et al., 2004b).

O APA pode ser considerado uma alternativa segura para o glutaraldeído (RIDEOUT et al., 2005) uma vez que seu uso diluído não tem sido associado com sensibilização respiratória ou dermatológica (RIDEOUT et al, 2005), especialmente em baixas concentrações (KUGNIGK; ALMEIDA, 2001), o que não acontece com o glutaraldeído que pode causar efeitos tóxicos nos profissionais que o manipulam e em seus pacientes (RIDEOUT et al., 2005). 


\section{PROPOSIÇÃO}

Avaliar a capacidade de desinfecção de solução de APA a $0,2 \%$ sobre bactérias Gram-positivas, Gram-negativas e fungos utilizando artigos termolábeis contaminados através de seu contato com a mucosa oral humana. 


\section{CASUÍSTICA-MATERIAL E MÉTODOS}

\subsection{Casuística}

Foram coletadas amostras em trinta pacientes, maiores de 18 anos, sem predileção por gênero ou etnia, que foram atendidos na clínica da Disciplina de Semiologia da Faculdade de Odontologia da Universidade de São Paulo, no período da manhã. Não foram levados em consideração o estado geral de saúde e o aspecto interno da cavidade bucal.

Como critério de exclusão foi observado o nível de entendimento dos pacientes, uma vez que só foi feita a coleta do material após a explicação, leitura e total e livre aceitação do consentimento livre e esclarecido (ANEXO A). As amostras foram processadas no Laboratório da Disciplina de Controle Biológico do Departamento de Farmácia da Faculdade de Ciências Farmacêuticas da Universidade de São Paulo para o processamento das amostras.

Esta pesquisa obteve Parecer de Aprovação dos Comitês de Ética em Pesquisa da Faculdade de Odontologia da Universidade de São Paulo sob Protocolo 187/06 (ANEXO B) e da Faculdade de Ciências Farmacêuticas da Universidade de São Paulo, sob Protocolo CEP n0 404 (ANEXO C). 


\subsection{Material}

O material necessário para a realização desta pesquisa segue descrito e dividido em material permanente e material de consumo.

\subsubsection{Material permanente}

- Agitador mecânico Minishaker MSI (Ika-Works Inc., Wllimington, EUA).

- Autoclave para esterilização e fundição dos meios de cultura (ATTC, Sercon, SP, BR).

- Balança semi-analítica (Modelo BG 1000, Gehaka, SP, BR).

- Bico de Bünsen (marca não especificada).

- Capela de fluxo laminar (Modelo Biosafe 12 CL-II tipo A, Veco, Campinas, SP, BR).

- Contador de colônias de microrganismos (Modelo CP 600 Plus, Phoenix, Araraquara, SP, BR).

- Copos de Becker graduados (marca não especificada).

- Cronômetro progressivo digital (cód. SW 2018, Cronobio, WMED, São Caetano do Sul, SP, BR).

- Dessecador ( $p /$ anaerobiose, marca não especificada).

- Estufa incubadora para bolores e leveduras BOD (Modelo 347-CD, Fanem, SP, $\mathrm{BR})$. 
- Estufa Incubadora para cultura bacteriológica BOD (Modelo 411D, Nova Ética, Vargem Grande Paulista, SP, BR).

- Microscópio ótico (Modelo B 472, Olympus, Japão).

- pHmetro (Modelo B474, Micronal, SP, BR).

- Pipeta automática de 200 a 1000 l e pontas estéreis (Modelo P1000, Gilson, França).

- Pinças e tesouras estéreis (marca não especificada).

- Tubos de ensaio de $150 \mathrm{~mm}$ x 25 mm x 22 mm (marca não especificada).

4.2.2 Material de consumo

- Ácido peracético a 0,2\% - Proxitane ${ }^{\circledR}$ Alfa (Peróxidos do Brasil, Curitiba, PR, BR). Mistura equilibrada constituída, segundo seu fabricante por:

Ácido peracético mín. 0,2\%

Peróxido de hidrogênio mín. 3,5\%

Veículo estabilizante qsp $100 \%$.

$\mathrm{pH}$ menor que 1,7 .

- Cento e vinte micro-aplicadores descartáveis de resina fotopolimerizável com ponta de tamanho regular como protótipo para material termolábil, (Cavibrush, FGM, Joinville/SC, BR).

- Detergente líquido natural biodegradável com lauril éter sulfato de sódioconcentração não especificada (500 ml, Sabel, SP, BR).

- Escova para limpeza das amostras (ref. 1121, Condor ${ }^{\circledR}$, São Paulo, SP, BR). 
- Lâminas de vidro para microscopia com largura de 26 mmx76 mm e espessura de 1,0 mm a 1,2 mm (Ref. 4-0521, Glasstécnica, São Paulo, SP, BR).

- Material para realização de coloração de Gram: cristal violeta, solução de iodoiodetado (Lugol), solução alcoólica de fucsina fenicada.

- Meios de cultura: ágar de caseína de soja e agar Sabouraud dextrose »Ágar caseína de soja -Tryptic Soy Agar/TSA (DIFCO/BD, Sparks, USA).

Para cultivo de uma variedade de microrganismos de espécies diferentes (PINTO; KANEKO; OHARA, 2000) sua fórmula aproximada por litro de água destilada é constituída por:

Digerido pancreático de caseína $15,0 \mathrm{~g}$.

Digerido enzimático de soja $5,0 \mathrm{~g}$.

Cloreto de sódio $5,0 \mathrm{~g}$. Agar $15,0 \mathrm{~g}$.

Água destilada q.s.p. $1000 \mathrm{ml}$ $\mathrm{pH}$ final $7,3 \pm 0,2$

Frascos de TSA foram preparados, conforme especificação do fabricante, esterilizados por 30 minutos a $124{ }^{\circ} \mathrm{C}$ e fundidos por 15 minutos a $124{ }^{\circ} \mathrm{C}$.

»Ágar Sabouraud dextrose-Sabouraud Dextrose Agar/SDA (DIFCO/BD, Sparks, USA).

Para o crescimento de bolores e leveduras (TORTORA; FUNKE; CASE, 2003), sua fórmula aproximada por litro de água de destilada constitui-se por:

Neopeptona

Dextrose

Agar

Água destilada

$\mathrm{pH}$ final
$10 \mathrm{~g}$

$40 \mathrm{~g}$

$11 \mathrm{~g}$

q.s.p. $1000 \mathrm{~mL}$

$5,6 \pm 0,2$

Os frascos de SDA foram preparados conforme especificação do fabricante, esterilizados por 30 minutos a $124{ }^{\circ} \mathrm{C}$ e fundidos por 15 minutos a $124{ }^{\circ} \mathrm{C}$. 
- Solução salina a $0,9 \%$

Para extração dos microrganismos e como diluente para as diluições decimais. Foi preparada conforme especificação do fabricante do cloreto de sódio 0,9\% (Carlo Erba, Rodano, Itália).

Cloreto de sódio

$9 \mathrm{~g}$

Água destilada

qsp $100 \mathrm{ml}$

Tubos de ensaio desta solução foram autoclavados a $120{ }^{\circ} \mathrm{C}$ por 15 minutos.

- Placas de Petri (poliestireno cristal) estéreis, descartáveis de $90 \mathrm{~mm} \times 15 \mathrm{~mm}$ (Disp-Petri, Alamar, Diadema, SP, BR).

- Trinta recipientes estéreis para acondicionamento e transporte de material contaminado (Labsynth ${ }^{\circledR}$, Diadema, SP, BR).

\subsection{Métodos}

\subsubsection{Coleta das amostras}

Após a leitura e compreensão do consentimento livre e esclarecido pelos trinta pacientes (ANEXO A) foi realizada, por um único examinador, coleta delicada do material com micro-aplicador descartável de resina (amostra) em quatro sítios da cavidade oral: mucosa jugal (lados direito e esquerdo), palato duro e dorso de língua. Para cada região utilizou-se um aplicador diferente. 
A coleta das amostras não ofereceu nenhum risco ou prejuízo aos pacientes, uma vez que o instrumento que foi utilizado é inócuo e aprovado pela ADA, para procedimentos odontológicos.

As amostras de um mesmo paciente foram colocadas em recipiente estéril de transporte. Os recipientes foram numerados de um a trinta, sendo acondicionados em caixa de isopor devidamente lacrada, que foi levada ao Laboratório da Disciplina de Controle Biológico do Departamento de Farmácia da Faculdade de Ciências Farmacêuticas da Universidade de São Paulo para o processamento das amostras.

\subsubsection{Separação e preparo das amostras}

Para evitar contaminação com o ambiente, cada amostra foi retirada do recipiente estéril de transporte, com pinças esterilizadas e em condições de assepsia (em câmara de fluxo laminar).

Das quatro amostras contidas nos recipientes, cada uma foi distribuída em quatro grupos para receberem tratamentos diferentes:

Grupo A (grupo controle): amostras sem lavagem com água e detergente e sem tratamento com o ácido peracético a 0,2\%.

Grupo B: amostras tratadas com ácido peracético a 0,2\%, por 10 min (para desinfecção, conforme orientação do fabricante) e sem lavagem com água e detergente, para verificar a ação do produto frente à presença de matéria orgânica.

Grupo C: amostras foram lavadas com água e detergente, sem tratamento com ácido peracético a $0,2 \%$. 
Grupo D: amostras lavadas com água e detergente e tratamento com desinfetante a base de ácido peracético a $0,2 \%$ por 10 min (para desinfecção, conforme orientação do fabricante).

\subsubsection{Extração dos microrganismos}

As amostras, depois de terem recebido tratamento específico para cada grupo acima mencionado, foram depositadas em tubos de ensaio contendo $9 \mathrm{ml}$ de solução salina a 0,9\% para extração dos microrganismos em agitação por trinta segundos, de acordo com a The United State Pharmacopeia (USP, 2005).

\subsubsection{Análise microbiológica}

Após a agitação de cada um das amostras, procederam-se diluições decimais de $10^{-1}, 10^{-2}, 10^{-3}$, que serviram para facilitar posterior contagem das UFC: a diluição $10^{-1}$ é a diluição inicial, a diluição $10^{-2}$ foi feita pipetando-se $1 \mathrm{ml}$ da diluição inicial para $9 \mathrm{ml}$ de solução salina e a diluição $10^{-3}$ foi preparada pipetando-se $1 \mathrm{ml}$ da diluição $10^{-2}$ para $9 \mathrm{ml}$ de solução salina, entre cada diluição as amostras foram homogeneizadas por trinta segundos. Alíquotas de $1 \mathrm{ml}$ foram pipetadas de cada uma das diluições para seis placas de Petri estéreis (Figura 4.1). 
Transferiram-se quantidades de 15 a $20 \mathrm{ml}$ de meio de cultura TSA e SDA para estas placas (em duplicata), para cada diluição, sendo homogeneizadas com movimentos suaves em forma de oito (cerca de oito vezes), para cultivo dos microrganismos, através de condições específicas, após solidificação do ágar (PINTO; KANEKO; OHARA, 2000).

As placas foram identificadas mostrando a diluição, tipo de meio e incubação a que foram submetidas (Figura 4.2).

4.2.5 Cultura de bactérias aeróbias

Após solidificação do ágar TSA, as placas foram invertidas e incubadas a 32,5 $\pm 2,5{ }^{\circ} \mathrm{C}$ por 48 horas, em estufa incubadora (PINTO; KANEKO; OHARA, 2000). Após o período de incubação, foi realizada a contagem das UFC.

4.2.6 Cultura de bactérias anaeróbias

Após solidificação do ágar TSA, as placas foram invertidas e incubadas as a $32,5 \pm 2,5{ }^{\circ} \mathrm{C}$ por 48 horas, em condições de anaerobiose, com a finalidade de detecção do desenvolvimento tanto de anaeróbicos facultativos como de estritos (TORTORA; FUNKE; CASE, 2003), que constituem a maioria da microbiota bucal. 
4.2.6.1 condições de anaerobiose

Para o cultivo de bactérias anaeróbias são necessárias condições especiais uma vez que o contato com oxigênio pode causar sua morte (TORTORA; FUNKE; CASE, 2003). As placas foram incubadas em recipiente no qual o oxigênio foi eliminado através de sistema de vácuo (PINTO; KANEKO; OHARA, 2000). Após o período de incubação, foi realizada a contagem das UFC.

4.2.7 Cultura de fungos

As placas com SDA já solidificado, $22,5 \pm 2,5^{\circ} \mathrm{C}$ foram invertidas e incubadas por sete dias para o crescimento dos fungos (PINTO; KANEKO; OHARA, 2000).

Após o período de incubação, foi realizada a contagem das UFC de bolores e leveduras.

4.2.8 Contagem da unidade formadora de colônia (UFC)

Com o auxílio do contador de colônias (Figura 4.3), procedeu-se a contagem das UFC das bactérias aeróbias, anaeróbias, bolores e leveduras sendo anotadas em tabela, de acordo a identificação que constava em sua etiqueta (Figura 4.4). 


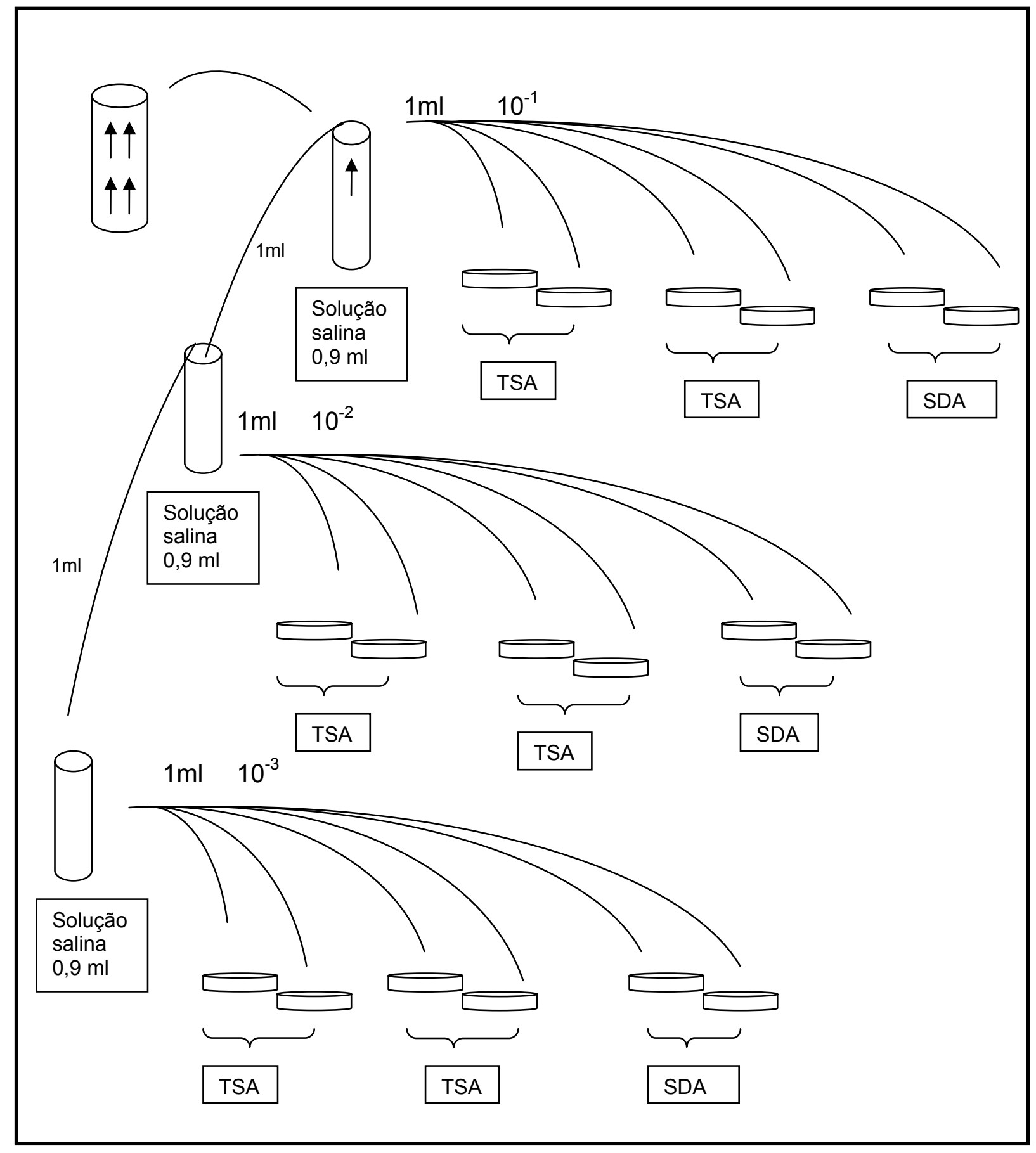

Figura 4.1 - Esquema da análise microbiológica 


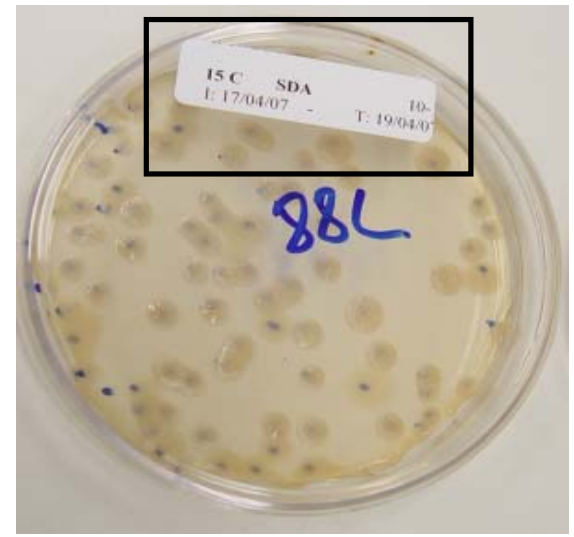

Figura 4.2 - Identificação das placas de Petri
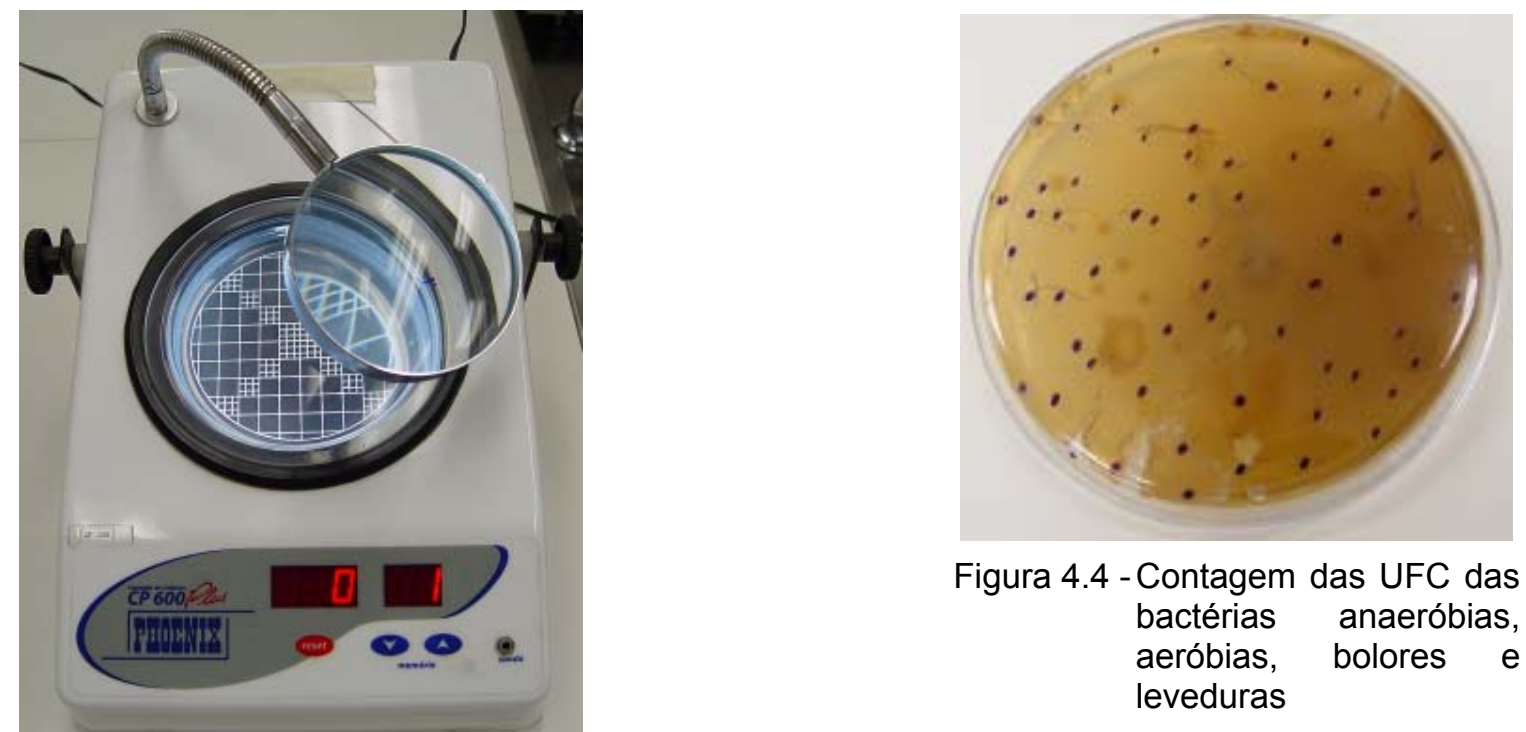

Figura 4.3- Contador de colônias de microrganismos (Modelo CP 600 Plus, Phoenix, Araraquara, SP, BR)

Figura 4.4 - Contagem das UFC das bactérias anaeróbias, aeróbias, leveduras 
4.2.9 Classificação das bactérias

Este procedimento se fez necessário para a classificação do tipo de bactérias, que estavam sendo manipuladas, sendo utilizada a coloração de Gram. Para este procedimento foram selecionadas UFC do grupo A (controle).

\subsubsection{1 coloração de Gram}

É uma das colorações diferenciais, uma vez que utiliza corantes que atuam diversamente sob bactérias distintas. É uma das mais utilizadas, uma vez que classifica as bactérias em dois grupos: Gram-positivas e Gram-negativas (TORTORA; FUNKE; CASE, 2003).

Para esta identificação por coloração de Gram, foram escolhidas as UFC que se assemelhavam por suas características macromorfológicas (forma, tamanho e cor). Foi realizada a identificação conforme o procedimento descrito a seguir.

A coloração se inicia pela aplicação de corante básico (cristal violeta), seguida de tratamento por uma solução de lugol, sendo que neste momento todas as bactérias mostram-se numa coloração roxa. Finalmente serão tratadas por solução alcoólica de safranina. As células Gram-positivas permanecem roxas, pois fixam o complexo cristal violeta; as Gram-negativas ficam descoradas pela fucsina fenicada aplicando-se a elas um corante de contraste para que adquiram uma coloração mais 
clara. Imediatamente após este processo ocorrerá a preparação das lâminas para observação ao microscópio óptico (TORTORA, FUNKE; CASE, 2003).

\subsubsection{2 observação microscópica e classificação}

A análise microscópica dos resultados frente à coloração de Gram foi realizada com lentes de aumentos de 40 e 100 vezes. Após observação microscópica foi constatado que se constituiu de cocos e bacilos Gram-negativos e Gram-positivos, com a predominância das Gram-negativas.

\subsubsection{Análise estatística}

4.2.10.1 análise estatística das bactérias anaeróbias

Depois de avaliada a normalidade dos dados, estes tiveram suas médias e respectivos desvios padrão analisados, como pode ser visto na tabela 4.1, a fim de determinar o teste mais adequado. Observou-se que os desvios padrão dos grupos estudados são aproximadamente iguais, portanto optou-se por utilizar a Análise de Variância (ANOVA) com nível de significância de 5\%. 
Tabela 4.1 - Médias, desvios-padrão e erros-padrão dos logaritmos da contagem de bactérias anaeróbias

\begin{tabular}{c|c|c|c|c}
\hline Grupo & Média & DP & N & EP \\
\hline Geral & 1,97 & 1,26 & 120 & - \\
A & 4,38 & 1,54 & 30 & 0,23 \\
B & 0,26 & 0,92 & 30 & 0,23 \\
C & 2,89 & 1,39 & 30 & 0,23 \\
D & 0,37 & 1,10 & 30 & 0,23 \\
\hline
\end{tabular}

Na tabela 4.2 pode-se observar que o valor de $F$ calculado é muito maior do que o valor de $F$ crítico, mostrando indícios de que pelo menos uma das médias dos grupos é diferente das demais.

Tabela 4.2 - ANOVA realizado com os logarítmos das contagens de bactérias anaeróbias

\begin{tabular}{c|c|c|c|c|c|c}
\hline & $S Q$ & $N G L$ & $Q M$ & $F$ & $p$ & $F$ critico \\
\hline Dentro & 184,60 & 116 & 1,591 & 76,40 & 0,0000 & 2,68 \\
Entre & 364,75 & 3 & 121,58 & & & \\
\hline
\end{tabular}

Uma vez observado os indícios de diferença estatisticamente significante em ao menos um dos grupos, utilizou-se o teste $t$ associado ao teorema de Bonferroni para avaliar qual dos grupos é diferente dos demais, desta forma foram calculados os valores de $t$ e os valores de $p$ para cada uma das comparações (Tabelas $4.3 \mathrm{e}$ 4.4).

Tabela 4.3 - Valor de $t$ para cada uma das comparações entre os grupos

\begin{tabular}{c|c|c|c}
\hline \multicolumn{4}{c}{$\boldsymbol{t}$} \\
\hline & $\mathrm{A}$ & $\mathrm{B}$ & $\mathrm{C}$ \\
\cline { 2 - 4 } $\mathrm{B}$ & 12,66 & & \\
$\mathrm{C}$ & 4,58 & 8,08 & \\
$\mathrm{D}$ & 12,33 & 0,33 & 7,75 \\
\hline
\end{tabular}


$\mathrm{Na}$ tabela 4.4 é possível observar que houve diferença estatisticamente significante em todas as comparações exceto entre os grupos B e D

Tabela 4.4 - Valor de $p$ para cada uma das comparações entre os grupos

\begin{tabular}{c|c|c|c}
\hline \multicolumn{3}{|c}{$\boldsymbol{p}$} \\
\hline & $\mathrm{A}$ & $\mathrm{B}$ & $\mathrm{C}$ \\
\cline { 2 - 4 } $\mathrm{B}$ & 0,00000 & & \\
$\mathrm{C}$ & 0,00003 & 0,00000 & \\
$\mathrm{D}$ & 0,00000 & 0,74 & 0,00000 \\
\hline
\end{tabular}

\section{Gráfico de Médias (DP)}

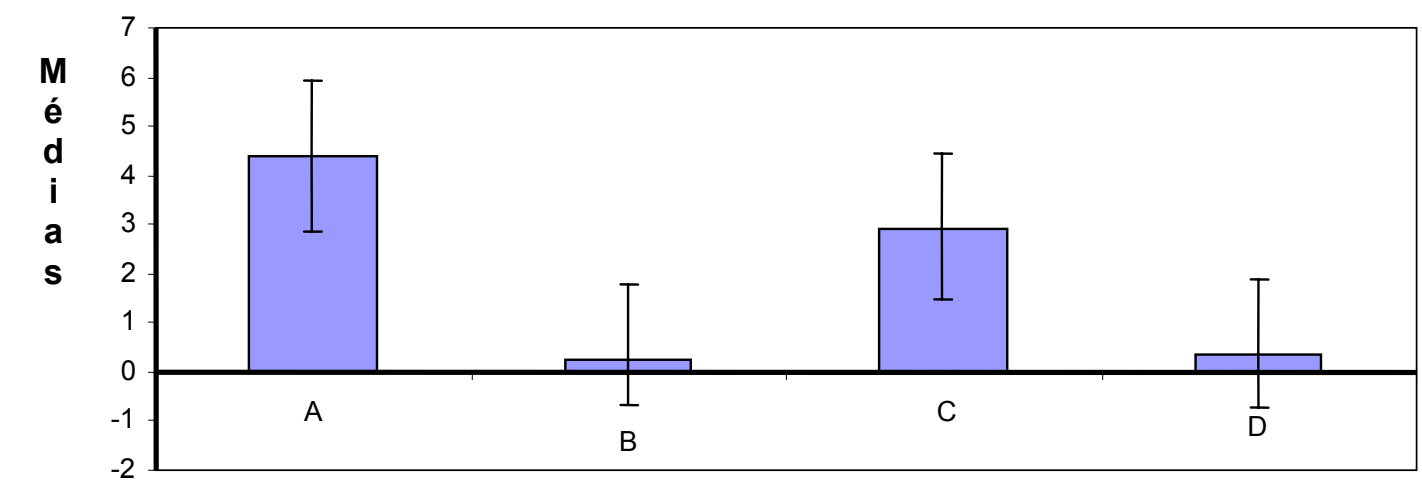

Grupos

Gráfico 4.1 -Médias e respectivos desvios-padrão dos logaritmos das contagens de bactérias anaeróbias 
4.2.10.2 análise estatística das bactérias aeróbias

Depois de avaliada a normalidade dos dados, estes tiveram suas médias e respectivos desvios padrão analisados, como pode ser visto na tabela 4.5 , a fim de determinar o teste mais adequado. Observou-se que os desvios padrão dos grupos estudados são aproximadamente iguais, portanto optou-se por utilizar a ANOVA com nível de significância de 5\%.

Tabela 4.5 - Médias, desvios-padrão e erros-padrão dos logaritmos da contagem de bactérias aeróbias

\begin{tabular}{c|c|c|c|c}
\hline Grupo & Média & $\boldsymbol{D P}$ & $\boldsymbol{N}$ & $\boldsymbol{E P}$ \\
\hline Geral & 1,95 & 1,35 & 120 & - \\
A & 4,07 & 1,76 & 30 & 0,25 \\
B & 0,34 & 1,05 & 30 & 0,25 \\
C & 2,93 & 1,27 & 30 & 0,25 \\
D & 0,47 & 1,24 & 30 & 0,25 \\
\hline
\end{tabular}

Na tabela 4.6 pode-se observar que o valor de $F$ calculado é muito maior do que o valor de $F$ crítico, mostrando indícios de que pelo menos uma das médias dos grupos é diferente das demais.

Tabela 4.6 -Anova realizado com os logaritmos das contagens de bactérias aeróbias

\begin{tabular}{c|c|r|r|c|c|r}
\hline & $S Q$ & $N G L$ & \multicolumn{1}{|c|}{$Q M$} & $F$ & $p$ & F critico \\
\cline { 2 - 7 } Dentro & 212,83 & 116 & 1,835 & 55,85 & 0,0000 & 2,68 \\
Entre & 307,43 & 3 & 102,475 & & & \\
\hline
\end{tabular}

Uma vez observado os indícios de diferença estatisticamente significante em ao menos um dos grupos, utilizou-se o teste $t$ associado ao teorema de Bonferroni, 
usado para corrigir o nível de significância global do teste $t$, para avaliar qual dos grupos é diferente dos demais, desta forma foram calculados os valores de $t$ e os valores de $p$ para cada uma das comparações (Tabelas 4.7 e 4.8).

Tabelas 4.7 -Valor de $t$ para cada uma das comparações entre os grupos

\begin{tabular}{c|c|c|c}
\hline \multicolumn{3}{|c}{$\boldsymbol{T}$} \\
\hline & $\mathrm{A}$ & $\mathrm{B}$ & $\mathrm{C}$ \\
\cline { 2 - 4 } $\mathrm{B}$ & 10,683 & & \\
$\mathrm{C}$ & 3,271 & 7,412 & \\
$\mathrm{D}$ & 10,291 & 0,392 & 7,020 \\
\hline
\end{tabular}

Na tabela 4.8 é possível observar que houve diferença estatisticamente significante em todas as comparações exceto entre os grupos B e D.

Tabelas 4.8 - Valor de p para cada uma das comparações entre os grupos

\begin{tabular}{c|c|c|c}
\hline \multicolumn{3}{|c}{$\boldsymbol{P}$} \\
\hline & $\mathrm{A}$ & $\mathrm{B}$ & $\mathrm{C}$ \\
\cline { 2 - 4 } $\mathrm{B}$ & 0,00000 & & \\
$\mathrm{C}$ & 0,00181 & 0,00000 & \\
$\mathrm{D}$ & 0,00000 & 0,70 & 0,00000 \\
\hline
\end{tabular}




\section{Gráfico de Médias (DP)}

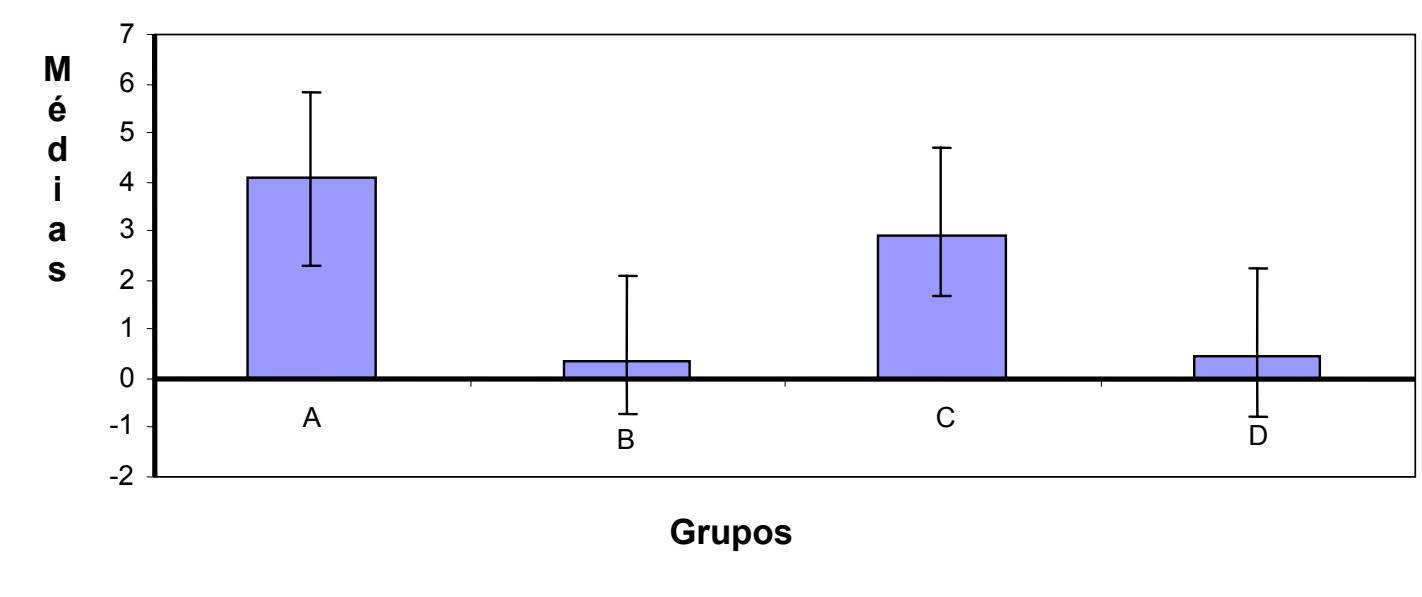

Gráfico 4.2 Médias e respectivos desvios padrão dos logaritmos das contagens de bactérias aeróbias

\subsubsection{2 análise estatística dos fungos}

Depois de avaliada a normalidade dos dados, estes tiveram suas médias e respectivos desvios padrão analisados, como pode ser visto na tabela 4.9 , a fim de determinar o teste mais adequado. Observou-se que os desvios padrão dos grupos estudados são aproximadamente iguais, portanto optou-se por utilizar a ANOVA com nível de significância de $5 \%$.

Tabela 4.9 - Médias, desvios padrão e erros padrão dos logaritmos da contagem de bolores e leveduras

\begin{tabular}{c|c|c|c|c}
\hline Grupo & Média & DP & $\boldsymbol{N}$ & EP \\
\hline Geral & 1,29 & 1,12 & 120 & - \\
A & 0,84 & 0,99 & 30 & 0,20 \\
B & 0,64 & 0,88 & 30 & 0,20 \\
C & 2,85 & 1,26 & 30 & 0,20 \\
D & 0,83 & 1,29 & 30 & 0,20 \\
\hline
\end{tabular}


Na tabela 4.10 pode-se observar que o valor de $F$ calculado é muito maior do que o valor de $F$ crítico, mostrando indícios de que pelo menos uma das médias dos grupos é diferente das demais.

Tabela 4.10 - Anova realizado com os logaritmos das contagens de fungos

\begin{tabular}{c|c|c|c|c|c|c}
\hline & $S Q$ & $N G L$ & $Q M$ & $F$ & $p$ & $F$ critico \\
\cline { 2 - 7 } Dentro & 145,021 & 116 & 1,2502 & 26,23 & 0,0000 & 2,68 \\
Entre & 98,375 & 3 & 32,7917 & & & \\
\hline
\end{tabular}

Uma vez observado os indícios de diferença estatisticamente significante em ao menos um dos grupos, utilizou-se o teste $t$ associado ao teorema de Bonferroni para avaliar qual dos grupos é diferente dos demais, desta forma foram calculados os valores de $t$ e os valores de $p$ para cada uma das comparações (Tabelas 4.11 e 4.12).

Tabela 4.11 - Valor de $t$ para cada uma das comparações entre os grupos

\begin{tabular}{c|c|c|c}
\hline \multicolumn{3}{|c|}{$\boldsymbol{t}$} \\
\hline & A & B & C \\
\cline { 2 - 4 } B & 0,709 & & \\
C & 6,964 & 7,673 & \\
D & 0,040 & 0,669 & 7,004 \\
\hline
\end{tabular}

Na tabela 4.12 é possível observar que o único grupo onde houve diferença estatisticamente significante foi o grupo C.

Tabela 4.12 - Valor de $p$ para cada uma das comparações entre os grupos

\begin{tabular}{c|c|c|c}
\hline \multicolumn{3}{|c}{$p$} \\
\hline & $\mathrm{A}$ & $\mathrm{B}$ & $\mathrm{C}$ \\
\cline { 2 - 4 } $\mathrm{B}$ & 0,48 & & \\
$\mathrm{C}$ & 0,00000 & 0,00000 & \\
$\mathrm{D}$ & 0,97 & 0,51 & 0,00000 \\
\hline
\end{tabular}




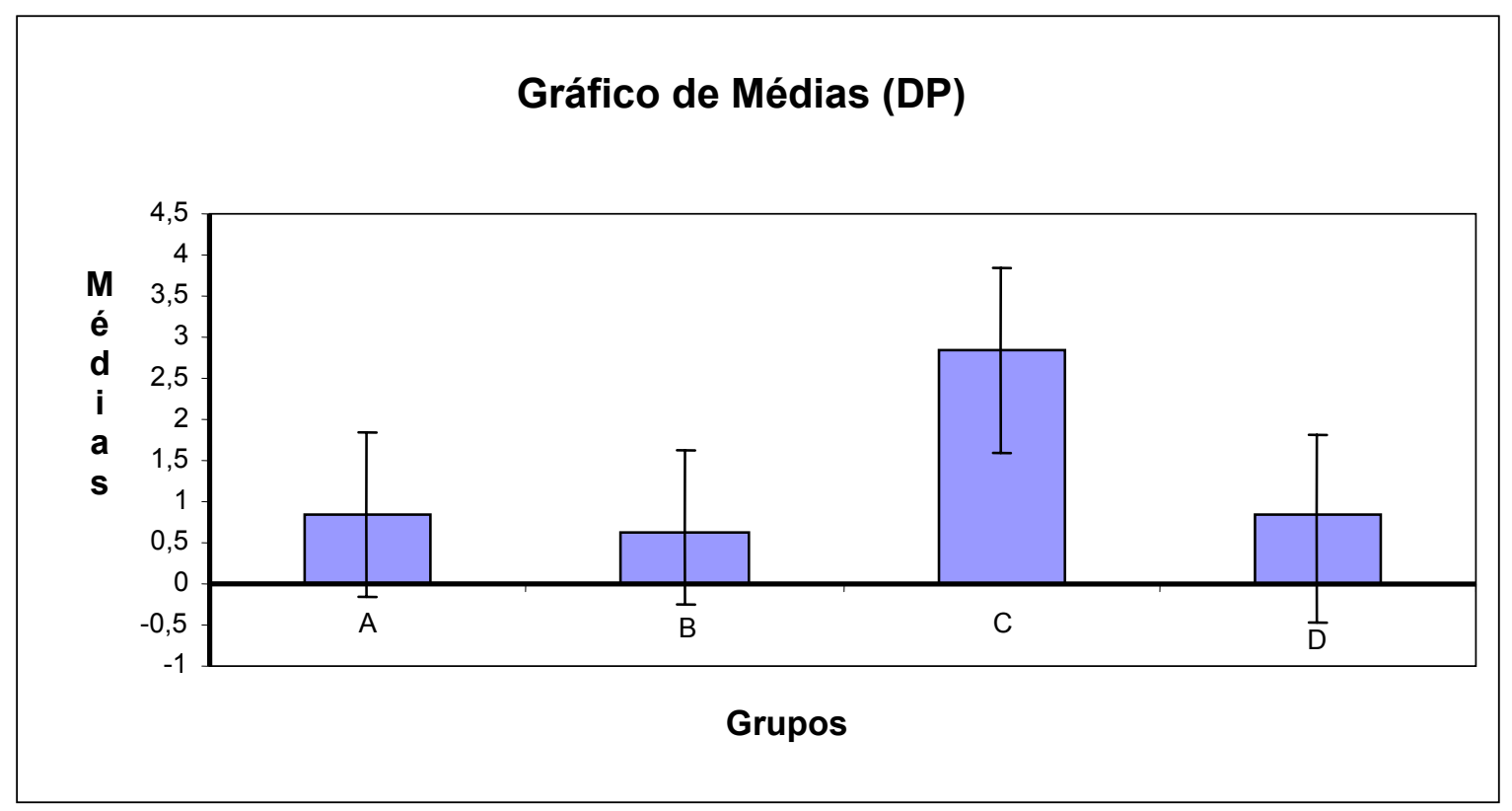

Gráfico 4.3 -Médias e respectivos desvios padrão dos logaritmos das contagens dos fungos

\subsubsection{3 análise estatística da microbiota oral}

Depois de avaliada a normalidade dos dados, estes tiveram suas médias e respectivos desvios padrão analisados, como pode ser visto na tabela 4.13 , a fim de determinar o teste mais adequado. Observou-se que os desvios padrão dos grupos estudados são aproximadamente iguais, portanto optou-se por utilizar a ANOVA com nível de significância de 5\%.

Tabela 4.13 - Médias, desvios padrão e erros padrão dos logaritmos da contagem de microbiota oral

\begin{tabular}{c|c|c|c|c}
\hline Grupo & Média & $\boldsymbol{D P}$ & $\boldsymbol{N}$ & $\boldsymbol{E P}$ \\
\hline Geral & 5,22 & 3,12 & 120 & - \\
A & 9,30 & 3,35 & 30 & 0,57 \\
B & 1,23 & 2,03 & 30 & 0,57 \\
C & 8,67 & 3,49 & 30 & 0,57 \\
D & 1,67 & 3,37 & 30 & 0,57 \\
\hline
\end{tabular}


$\mathrm{Na}$ tabela 4.14 pode-se observar que o valor de $F$ calculado é muito maior do que o valor de $F$ crítico, mostrando indícios de que pelo menos uma das médias dos grupos é diferente das demais. Tabela 4.14 - Anova realizado com os logaritmos das
contagens da microbiota oral

\begin{tabular}{c|c|r|c|c|c|r}
\hline & $S Q$ & $N G L$ & QM & $F$ & $p$ & F critico \\
\cline { 2 - 7 } Dentro & 1127,39 & 116 & 9,72 & 58,67 & 0,0000 & 2,68 \\
Entre & 1710,62 & 3 & 570,21 & & & \\
\hline
\end{tabular}

Uma vez observado os indícios de diferença estatisticamente significante em ao menos um dos grupos, utilizou-se o teste $t$ associado ao teorema de Bonferroni para avaliar qual dos grupos é diferente dos demais, desta forma foram calculados os valores de $t$ e os valores de p para cada uma das comparações (Tabelas 4.15 e 4.16).

Tabela 4.15 - Valor de $t$ para cada uma das comparações entre os grupos

\begin{tabular}{c|c|c|c}
\hline \multicolumn{3}{|c}{$\boldsymbol{t}$} \\
\hline & $\mathrm{A}$ & $\mathrm{B}$ & $\mathrm{C}$ \\
\cline { 2 - 4 } $\mathrm{B}$ & 10,017 & & \\
$\mathrm{C}$ & 0,775 & 9,241 & \\
$\mathrm{D}$ & 9,473 & 0,544 & 8,698 \\
\hline
\end{tabular}

$\mathrm{Na}$ tabela 4.16 é possível observar que houve diferença estatisticamente significante em todas as comparações exceto entre os grupos B e D e entre os grupos A e C. 
Tabela 4.16 - Valor de $p$ para cada uma das comparações entre os grupos

\begin{tabular}{c|c|c|c}
\hline \multicolumn{3}{|c}{$\boldsymbol{p}$} \\
\hline & $\mathrm{A}$ & $\mathrm{B}$ & $\mathrm{C}$ \\
\cline { 2 - 4 } $\mathrm{B}$ & 0,00000 & & \\
$\mathrm{C}$ & 0,44 & 0,00000 & \\
$\mathrm{D}$ & 0,00000 & 0,59 & 0,00000 \\
\hline
\end{tabular}

\section{Gráfico de Médias (DP)}

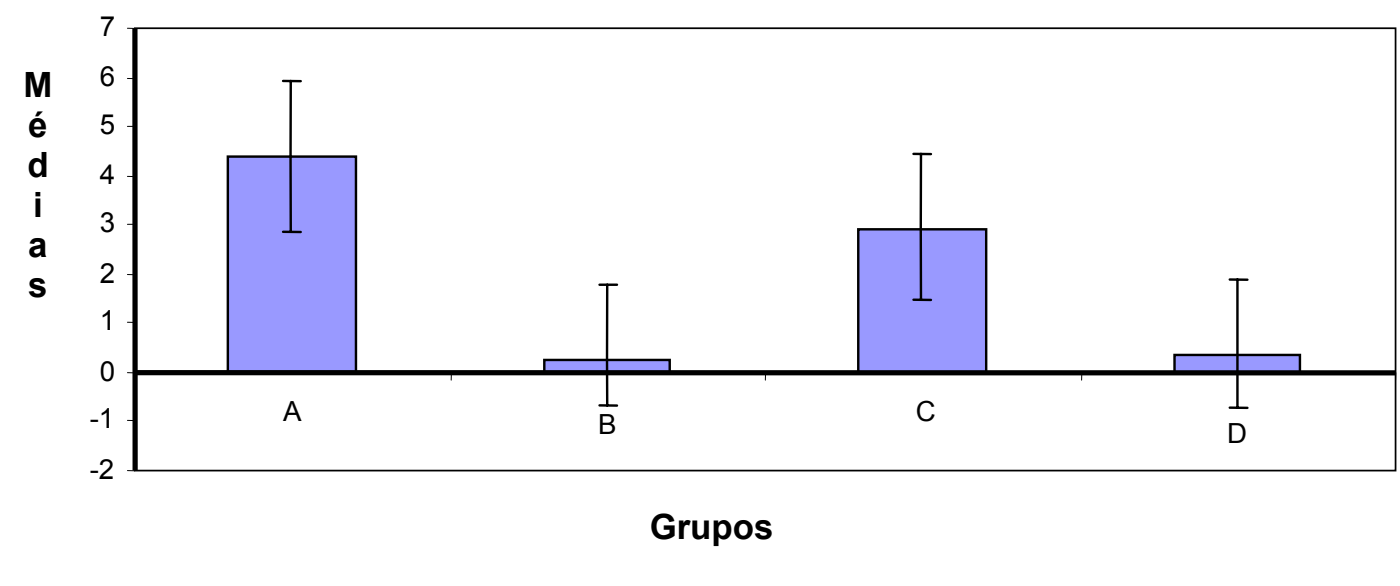

Gráfico 4.4-Médias e respectivos desvios-padrão dos logaritmos das contagens da microbiota oral 


\section{RESULTADOS}

\subsection{Bactérias Anaeróbias}

Para as bactérias anaeróbias, foi encontrada uma redução da contagem de microrganismos de colonização estatisticamente significante dos grupos $B, C$, e D, com média de 4,23, em relação grupo controle $(A)$.

Foi possível observar que o grupo B (somente APA) com média 0,26 e o grupo D (água, sabão e ácido) com média de 0,37 não apresentaram diferença estatisticamente significante entre si, porém apresentaram esta diferença quando comparados ao grupo C (água e sabão) com de média 2,89.

\subsection{Bactérias Aeróbias}

Entre as bactérias aeróbias, foi encontrada uma redução estatisticamente significante entre os grupos B, C e D, com média de 4,07, em relação grupo controle (A).

Observamos que o grupo B (APA) com de média 0,34 e o grupo D (água, sabão e APA) teve de média 0,47 não apresentaram diferença estatisticamente significante entre si, porém apresentaram esta diferença quando comparados ao grupo C (água e sabão) com média de 2,93. 


\subsection{Fungos}

Em relação aos fungos, foi encontrado um aumento estatisticamente significante entre o grupo $(C)$ água e sabão com média 2,85 , enquanto que os grupos B e D apresentaram uma redução pouco significante em relação ao grupo A., pois não houve diferença significante quando comparados ao grupo controle, com média de 0,84 , com o grupo $B$, com média 0,64 , e grupo $D$, com média 0,83 . A carga inicial de fungos para o grupo A foi baixa (Gráfico 5.1)

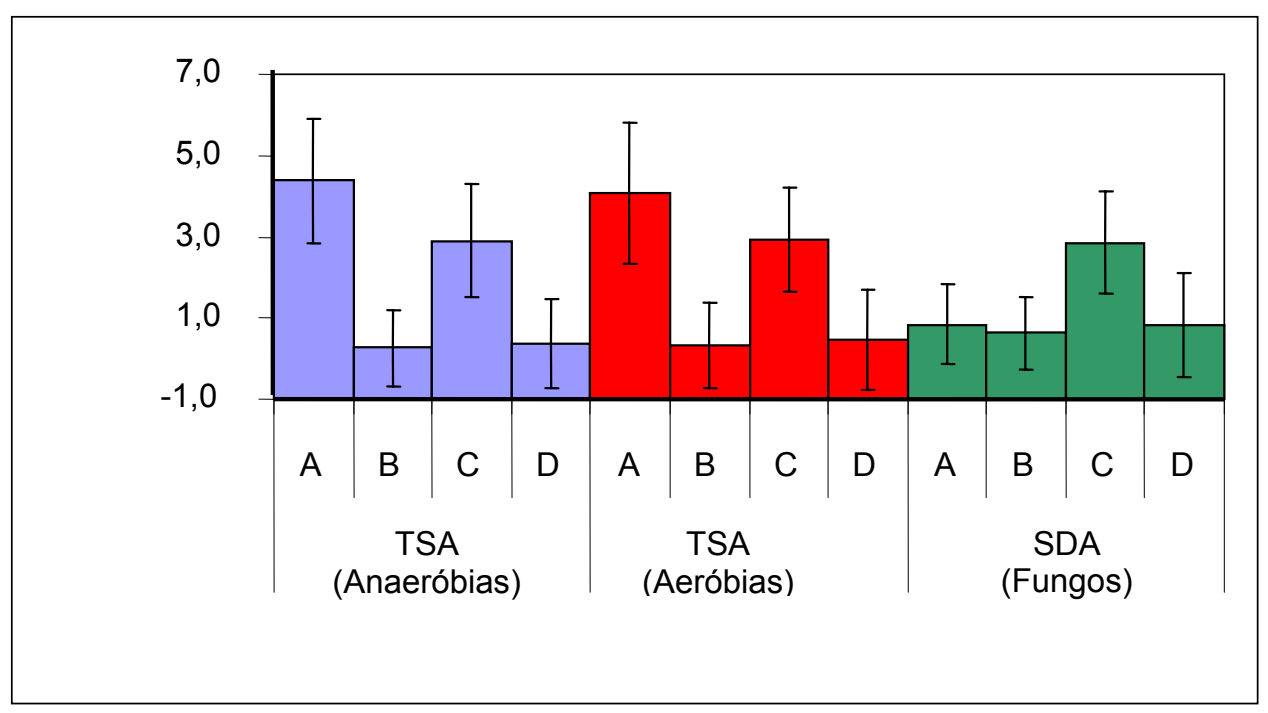

Gráfico 5.1 - Média das contagens dos microrganismos 


\subsection{Microbiota oral mista}

Para a microbiota oral em geral, foi encontrada diferença estatisticamente significante entre o grupo controle com média 3,1 e todos os demais grupos, sendo que para estes houve redução estatisticamente significante da contagem de microrganismos.

Verificamos que o grupo $B$, com média 0,41 , e grupo $D$, com média 0,56 , não apresentaram diferença estatisticamente significante entre si, porém apresentaram discrepância de forma significante quando comparados ao grupo C com média 2,89.

A redução das UFC da microbiota oral, após os tratamentos, em relação ao grupo A (controle) foi para o grupo B foi de 2,69; do grupo A em relação ao grupo C foi de 0,21 ; do grupo $A$ em relação ao grupo $D$ foram de 2,54. A partir da transformação logarítmica as contagens de UFC: A (1.290 UFC/ml), B (3 UFC/ml), C (776 UFC/ml), D (4 UFC/ml). 


\section{DISCUSSÃO}

Os métodos físicos, por sua eficiência, são mais usados para a esterilização de materiais odontológicos capazes de suportar altas temperaturas e pressões, mas pode ser necessário o processamento de materiais e instrumentos termolábeis. Diversos produtos químicos são usados para desinfecção e esterilização de destes tipos de itens utilizados em procedimentos das áreas da saúde. Alguns deles são altamente nocivos ao profissional, aos pacientes e meio ambiente (BORGES, 2005; GUIMARÃES JÚNIOR, 2001).

O APA é considerado um desinfetante seguro para os profissionais e pacientes (RIDEOUT et al., 2005), sendo ainda pouco utilizado pela classe odontológica o que nos sugeriu o presente estudo, sabendo que os tecidos orais são colonizados por microrganismos de natureza muito variável (JORGE, 1998).

Apesar de ser um produto químico conhecido desde 1902 e ter comprovada eficácia, ainda não temos um número de pesquisas capazes de torná-lo mais utilizável pelos cirurgiões-dentistas.

$\mathrm{Na}$ área médico-hospitalar é usado para desinfecção de endoscópios flexíveis (RUTALA; WEBER, 1999). De acordo com muitos estudos, o APA possui efeito antimicrobiano contra biofilmes em linhas de água em aparelhos para hemodiálise (LYNAM; BABB; FRAISE, 1995). O APA tem ação viruscida comprovada, que pode ser aumentada, quando é associado ao etanol a $80 \%$ observando-se a inativação dos vírus em tempo reduzido, sendo que esta associação está sendo utilizada como desinfetante de mãos, não se conhecendo nenhum efeito tóxico (WUTZEL; SAUERBREI, 2000), um fato muito importante uma vez que uma das principais 
formas de prevenção de infecções nosocomiais começa pela lavagem das mãos e sua anti-sepsia.

Estudos também estão sendo realizados quanto sua utilização para desinfecção de enxerto homólogo de tendão patelar, não ocorrendo alterações em termos de biocompatibilidade e biomecânica e combinado com altas concentrações de glicerol e propilenoglicol mostrou ser eficaz no reprocessamento de pele contaminada de cadáveres para enxertos homólogos, sem causar efeitos citotóxicos, pro - inflamatórios ou inibitórios da colagenase (LOMAS et al., 2004a; LOMAS et al., 2004b).

Por ser considerado um produto seguro e de ação rápida, é utilizado como desinfetante e esterilizante em muitas indústrias como as de processamento de alimentos, bebidas, médicas, farmacêuticas, como agente descolorante em indústria têxtil, de papel e polpa (KITIS, 2004). Sob forma de aerossol serve para esterilização de salas estéreis e manutenção de animais gnotobióticos (BLOCK, 1991).

Conforme Kugnik e Almeida (2001) o APA atua numa escala ampla de variação de temperatura e de $\mathrm{pH}$, sendo que para Baldry (1983) o pH ácido favoreceu sua ação antimicrobiana. A possibilidade de atuar em diferentes temperaturas favorece seu uso no país mercê de alterações climáticas intensas e de diversidade atmosféricas regionais. Apesar disto, como todo peroxigênio o melhor é estocá-lo em lugares com temperatura não superior a $30{ }^{\circ} \mathrm{C}$ e em sua embalagem escura própria (BLOCK, 1991).

O APA não reage quimicamente com vidro e muitos tipos de plásticos, porém, reage com algumas formulações de vinil, borrachas sintéticas e naturais. Muitos materiais quando colocados sob ação do APA podem sofrer corrosão como aço 
galvanizado, cobre, bronze e latão. Já, os que apresentam resistência a este desinfetante são alumínio puro e aço inox (KITIS, 2004).

O APA é ecologicamente correto por ser biodegradável e seus resíduos não serem tóxicos, pois sua decomposição resulta na formação de água, ácido acético, oxigênio e peróxido de hidrogênio (BORGES, 2005; TORTORA; FUNKE; CASE, 2003). Essa inocuidade ambiental não é apresentada pelos outros desinfetantes como os glutaraldeídos e formaldeídos e compostos iodados, quaternários de amônia, fenólicos e clorados.

Os resíduos da decomposição do APA são atóxicos, porém, não deve ser descartada a hipótese da formação de produtos mutagênicos, mesmo sabendo que seu potencial de mutagenicidade é baixo (MONARCA et al., 2002).

A atividade desinfetante do APA se dá pela liberação do oxigênio ativo (BLOCK, 1991) e radical hidroxi (CHASSOT; POISL; SAMUEL, 2006) que causa a oxidação das ligações SS (sulfidril) e SH (sulfidrila) dos microrganismos, ocorrendo o aumento da permeabilidade da parede celular, conteúdo citoplasmático e material genético interferindo assim, em suas reações químicas de sobrevivência e reprodução celular (CHASSOT; POISL; SAMUEL, 2006; KITIS, 2004; MCDONNEL; RUSSEL, 1999).

O APA possui um amplo espectro de ação antimicrobiana, inativando e eliminando fungos, vírus e bactérias em forma vegetativa e esporulada, mesmo na presença de matéria orgânica (BLOCK, 1991; BORGES, 2005; GRAZIANO; SILVA; BIANCHI, 2000). A existência de matéria orgânica não impede sua atuação, apesar de jamais se excluir a necessidade de limpeza prévia dos instrumentos, porém, quando a mesma não é feita com a necessária acurácia, não fica comprometida sua eficácia Também obtivemos resultados positivos no grupo que não recebeu pré- 
lavagem ocorrendo uma redução bastante significativa e sem uma diferença significante em relação ao grupo que passou pela lavagem com água e detergente.

Sua ação é rápida em tempo de imersão reduzido, sendo bem menor que o de outras substâncias, entre elas, o glutaraldeído (BORGES, 2005). Embora o tempo de desinfecção do APA não seja muito vantajoso, seu tempo de esterilização é consideravelmente menor, indicando que temos um caminho a percorrer estudando as possibilidades do APA frente as necessidade de esterilização em tempo curto.

O produto por nós usado tem recomendação do fabricante para ser usado em 10 minutos para desinfecção e uma hora para esterilização, na concentração de $0,2 \%$.

Chassot, Poisl e Samuel (2006) comprovaram que o APA, usado para desinfecção foi eficaz contra bactérias Gram-negativas e Gram-positivas que colonizaram as placas de resina in vitro e in vivo de sua pesquisa. Este estudo concorda com o nosso em que ocorreu redução estatisticamente significante das bactérias Gram-negativas e Gram-positivas.

Angelillo et al. (1998) comprovaram que um determinado desinfetante a base de peroxigênios pode ser usado para desinfecção, em quinze minutos, de diferentes instrumentos odontológicos, já nossa pesquisa comprovou o uso do APA para desinfecção em dez minutos da microbiota oral. Em relação ao grupo controle ocorreu uma redução significante dos dois grupos (B e D) que receberam tratamento com APA, em quantidades de UFC, de 1.290 UFC/ml do grupo controle (A) houve redução de 3 a 4 UFC/ml nos grupos $B$ e D respectivamente.

Para Kitis (2004), o APA na concentração de 0,003\% tem ação fungicida. Em estudo in vitro de Vizcaino-Alcaide, Herruzo-Cabrera e Fernandez-Aceñero (2003) um desinfetante a base de peroxigênios com concentração não especificada, obteve 
ação sob leveduras com fator de redução de 3,7 em vinte minutos em relação a um outro desinfetante a base de glutaraldeído que teve fator de redução de 2,1 no mesmo tempo, concluindo-se que o primeiro eliminou um número maior de leveduras que o segundo.

Nossos resultados, em relação aos fungos, mostraram uma redução pouco significante após o tratamento com APA, porém, isso se deveu à carga inicial que já foi pequena, uma vez que nossa coleta foi realizada in vivo, e por isso dependente de muitas variáveis. Entre estas está a hora do dia que a coleta é feita, pois a microbiota oral apresenta diferenças ao longo do dia relacionadas á higiene bucal e á dieta (JORGE, 1998). Tal fato não foi levado em consideração, uma vez que nossa intenção foi de obter condições reais do atendimento odontológico diário, porém, nossas coletas foram todas realizadas num mesmo período do dia.

O APA é esporicida mesmo em baixas concentrações (BALDRY, 1983; BLOCK, 1991). De acordo com o estudo de Chassot; Poisl e Samuel (2006) o APA a $0,2 \%$ proporcionou esterilização, eliminando esporos das cepas de Bacillus subtilis e Bacillus stearothermophilus em artigos semicríticos. Devido à sua termorresistência, estes microrganismos são usados como indicadores para monitoração biológica ao se comprovar a eficácia de estufas e autoclaves respectivamente.

Para Angelillo et al. (1998) esporos de Bacillus subtilis necessitaram de maior tempo de imersão dos instrumentos dentais, quando utilizaram um desinfetante à base de peroxigênios com concentração não especifica. A atividade esporicida, ou seja, esterilizante do APA não foi testada em nossa pesquisa, mas poderá vir a ser objeto de outros estudos futuros.

A literatura aponta que o APA é um eficiente agente micobactericida, uma ação importante, uma vez que as micobactérias apresentam resistência ao 
tratamento com glutaraldeído a $2 \%$ e a outros desinfetantes, por isso, é usado para a desinfecção de broncoscópios (MIDDLETON; CHADWICK; GAYA, 1997). A ação micobactericida é considerada como o fator de avaliação qualitativa de desinfetantes (GUIMARÃES JÚNIOR, 2001).

O APA mostrou ação bactericida rápida contra Staphylococcus aureus e Pseudomonas aeruginosa, Legionella pneumophila (DITOMMASO et al., 2005; LAMBERT; JOHNSTON; SIMONS, 1999) bactérias que contaminam sistemas de água e estão relacionadas a infecções hospitalares. Mostrou ser eficiente, no controle da contaminação microbiana na água de tratamento e da existência de biofilme na linha de água de unidade dentária (MONTEBUGNOLI et al., 2004), o que é muito interessante, pois o problema de desinfecção dos condutos de água de consultórios odontológicos é muito comentado atualmente. Ressalte-se que, por ser fortemente oxidante, o APA poderá corroer condutos metálicos a ele sensíveis.

Sua ação contra biofilmes e a contaminação da água deve ser muito bem considerada, pois é sabido que a atividade odontológica se utiliza de uma variedade muito grande de condutos onde o biofilme é capaz de se produzir. A preocupação com estes contaminadores está presente na inquietação e dificuldades dos que atualmente pesquisam a biossegurança e ainda não estão resolvidas.

Quando se deseja usar o APA na desinfecção de biofilmes, deve ser escolhida uma formulação que possua surfactantes catiônicos para que se evite a fixação dos mesmos, fato que também é conhecido entre os aldeídos, particularmente o glutaraldeído. Algumas marcas comerciais de APA foram testadas e, as que não possuíam surfactantes, não foram capazes de remover bioflimes e, pior, conseguiram fixá-los (LOUKILI et al., 2004; LOUKILI et al., 2006). 
O APA pode ser uma alternativa para desinfecção de efluentes primário, secundário e terciário de esgotos (KOIVUNEM; HEINONEN-TANSKI, 2005), porém, para Liberti e Notarnicola (1999) pode ocorrer o aumento de conteúdo orgânico nos efluentes urbanos por causa do ácido acético que é originado pela sua decomposição que pode ocasionar um novo crescimento microbiano, esta possibilidade precisa ser mais bem estudada, face às preocupações que temos frente aos danos desses efluentes ao ecossistema fluvial.

O APA pode ser uma alternativa segura para o glutaraldeído (RIDEOUT et al., 2005) uma vez que seu uso diluído não tem sido associado com sensibilização respiratória ou dermatológica (RIDEOUT et al., 2005), especialmente em baixas concentrações (KUGNIGK; ALMEIDA, 2001), o que não ocorre com o glutaraldeído que pode causar efeitos tóxicos dos profissionais em seus pacientes (RIDEOUT et al., 2005). 


\section{CONCLUSÕES}

Através de nossa pesquisa podemos concluir que o APA a $0,2 \%$, no tempo de dez minutos:

1. O APA nesta concentração e tempo de uso foi eficaz na redução das bactérias Gram-negativas e Gram-positivas.

2. A lavagem com água e detergente das amostras mostrou redução das bactérias Gram-positivas e Gram-negativas em relação ao grupo controle mostrando a necessidade da remoção mecânica eficaz das sujidades e matéria orgânica (ex. sangue, saliva e secreções inflamatórias) e inorgânica (ex. materiais odontológicos) visível nos instrumentais para impedir que os resíduos possam interferir na eficácia da desinfecção e da esterilização.

3. A matéria orgânica não inativa a ação do APA, uma vez que não houve redução significante da microbiota oral entre o grupo em que não foi realizada e o que foi realizada a pré-lavagem.

4. Em relação aos fungos, observou-se redução pouco significativa após o tratamento com APA, pois a carga inicial foi muito pequena, o que recomenda uma nova pesquisa in vitro.

5. O APA reduziu significativamente a microbiota oral. Mostrou ser eficaz para a desinfecção de instrumentos contaminados pela microbiota oral mista o que o recomenda para uso odontológico. 


\section{REFERÊNCIAS ${ }^{1}$}

ANVISA Agência Nacional de Vigilância Sanitária. Higienização das mãos em serviço de saúde. Disponível em URL: http://www.anvisa.gov.br/hotsite/higienização_maos/manua_integra.pdf [2007 jun.2].

Angelillo IF, Bianco A, Nobile CGA, Pavia M. Evaluation of the efficacy of glutaral dehyde and peroxigen for disinfection of dental instruments. Lett Appl Microbiol. 1998;27(5):292-96.

Baldry MG. The bactericidal, fungicidal and properties of hydrogen peroxide and peracetic acid. J Appl Bacteriol 1983;54(3):417-23.

Bertani TD, Fukunaga D, Lascala CA. Controle de infecção em Imaginologia DentoMaxilo-Facial. Rev Odontol UNICID 2004;16(2):183-6.

Berti M, Moimaz SAS, Ayres JPS. Métodos de Controle de infecção cruzada; uma avaliação do emprego na prática odontológica. Rev Paul Odontol 2003;25(5):34-7.

Block SS. Disinfection, sterilization and preservation. Philadelphia: Lea \& Fibiger; 1991.cap.9, p.167-81.

Borges LC. Ácido peracético: uma revolução na biossegurança. Disponível em URL: http://www.apcd-saúde.or.br/artigo.asp?cdnotícia=1\&numero=2 [2005 dez. 1].

Brasil. Decreto-lei $n^{\circ} 2.848$, de 7 de dezembro de 1940 alterado pela lei $n^{\circ} 9.777$ em 26 de dezembro de 1998- Código Penal Brasileiro. Perigo para a vida ou saúde de outrem. Disponível em URL: http://www.trece.gov.br/tre/institucional/cre/legislação/CP [2007a jun.2].

Brasil. Ministério da Saúde. Secretaria de Assistência à Saúde Departamento de Assistência e Promoção à Saúde. Coordenação de Controle de Infecção Hospitalar. Processamentos de artigos e superfícies em estabelecimentos de Saúde. $2^{\mathrm{a}}$ ed. Brasília: Editora MS; 1994.

${ }^{1}$ De acordo com Estilo Vancouver. Abreviatura de periódicos segundo base de dados MEDLINE. 
Brasil. Ministério da Saúde. Legislação em Vigilância Sanitária. Resolução RE $n^{0}$ 2586, de 10 de agosto de 2006. Altera o item "e" da Portaria $n^{\circ} 122 / D T N$, de 29 de novembro de 1993. Disponível em URL: http:// www.anvisa.gov.br/e-legis [2007b jun.2].

Chassot ALA, PoisI MIP, Samuel SMW. In vivo and in vitro evaluation of the efficacy of a peracetic acid-based disinfectant for decontamination of acrylic resins. Braz Dent J 2006:17(2):117-21.

Crebelli R, Conti L, Monarca S, Feretti D, Zerbini I, Zani C, et al. Genotoxicity of the disinfection by-products resulting from peracetic acid or hypochlorite-disinfected sewage wastewater. Water Res 2005;39(60):1105-13.

Ditommaso S, Biasin C, Giacomuzzi M, Cavanna A, Rugenini AM. Peracetic acid in the disinfection of a hospital water system contaminated with Legionella species. Infect Control Hosp Epidemiol 2005;26(5):490-3.

Eleazer PD; Schuster GS; Weathers DR. A chemical treatment regimen to reduce bacterial contamination in dental waterlines. J Am Dent Assoc. 1997;128(5):617-23.

Faraco FN, Moura APF. Controle do risco de transmissão de doenças infectocontagiosas no consultório odontológico Parte II. Rev Paul Odontol 1993;15(1):2832.

FIOCRUZ Fundação Oswaldo Cruz. Glossário em biossegurança. Disponível em URL: http://www.fiocruz.br/biossegurança/Bis/startBis.html [2006 dez. 1].

Graziano KU, Silva A, Bianchi ERF. Limpeza, desinfecção, esterilização de artigos e anti-sepsia. In: Fernandes AT. Infecção hospitalar e suas interfaces na área da saúde. $1^{a}$ ed. São Paulo: Atheneu; 2000. p. 266-304.

Griffiths PA, Babb JR, Fraise AP. Mycobactericidal activity of selected disinfectants using a quantitative using a quantitative suspension test. J Hosp Infect 1999;41(2):111-21.

Guimarães Júnior J. Biossegurança e controle de Infecção cruzada em consultórios odontológicos. $1^{a}$ ed. São Paulo: Santos; 2001.

Guimarães Júnior J. Controle de infecção cruzada no consultório odontológico. Rev Assoc Paul Cir Dent 1992;46(2):711-16. 
Jorge AOC. Microbiologia bucal. $2^{a}$ ed. São Paulo: Santos; 1998.

Jorge AOC, Koga-Ito CY, Maegi B, Barbosa APP, Komiyama EY. Desinfecção de Superfície em odontologia; Avaliação do Álcool Gel. 70 INPM, lenços embebidos em solução de clorexidina e Spray de cloreto de benzalcônio. RGO 2005;53(2):85164.

Kitis M. Disinfection of wastewater with peracetic acid: a review. Environ Int 2004;30(1):47-55.

Kugnigk L, Almeida MCB. Action of peracetic acid on Escherichia coli and staphylococcus aureus in suspension or settled on stainless stell surfaces. Braz $\mathrm{J}$ Microbiol 2001;32(1):38-41.

Koivunen J, Heinonen-Tanski $H$. Peracetic acid (PAA) disinfection of primary, secondary and treated municipal wastewaters. Water Res 2005;39(18):4445-53.

Kunigk L, Almeida MCB. Action of peracetic on Escherichia Coli and Staphylococcus Aureus in suspension or settled on stainless steel surface. Braz $\mathrm{J}$ Microbiol $2001 ; 32(1): 38-41$.

Lambert RJW, Johnston MD, Simons EA. A kinetic study of the effect of hydrogen peroxide and peracetic against staphylococcus aureus and Pseudomonas aeruginosa using the Bioscreen disinfection method. $J$ Appl Microbiol 1999;87(5):782-86.

Leoni E, Sacchetti R, Zanetti F, Legnani PP.Control of Legionella pneumophila contamination in a respiratory hydroterapy system with sulfurous spa water. Infect Control Hosp Epidemiol 2006;27(7):716-21.

Liberti L, Notarnicola M. Advanced treatment and disinfection for municipal wastewater reuse in agriculture. Water Sci Technol 1999;40(4-5):235-45.

Lomas RJ, Jennings LM, Fisher J, Kearney JN. Effects of a peracetic acid disinfection protocol on the biocompatibility and biomechamical properties of human patellar tendon allografts. Cell Tissue Bank 2004a;5(3):149-60.

Lomas RJ, Huang Q, Pegg DE, Kearney JN. Application of a high-level peracetic acid disinfection protocol to re-process antibiotic disinfected skin allografts. Cell Tissue Bank 2004b;5(1):23-36. 
Loukili NH, Becker H, Harno J, Bientz M, Meunier O. Effect of peracetic and aldehyde disinfectants on biofilm. J Hosp Infect 2004;58(2):151-4.

Loukili NH, Granbastien B, Faure K, Guery B, Beaucaire G. Effect of different stabilized preparations of peracetic acid on biofilm. J Hosp Infect 2006;63(1):70-2.

Lynam PA, Babb JR, Fraise AP. Comparison of the mycobactericidal activity of $2 \%$ alkaline glutaraldehyde and "Nu-Cidex"(0,35\%) peracetic acid.J Hosp Infect 1995;30(3):237- 40.

McDonnel G, Russel AD. Antiseptics and disinfectants: activity, action and resistance. Clin Microbiol Rev 1999;12(1):147-79.

Middleton AM, Chadwick MV, Gaya H. Disinfection of bronchoscopes, contaminated in vitro with Mycobacterium avium-intracellulare and Mycobacterium chelonae in sputum, using stabilized, buffered peracetic acid solution. J Hosp Infect 1997;37(4):137-43.

Monarca S, Richardson SD, Feretti D, Grottolo M, Thruston Jr AD, Zani C et al. Mutagenicity and disinfection by products in surface drinking water disinfected with peracetic acid. Environ Toxicol Chem 2002;21(2):309-18.

Molinari JA. Dental infection control at the year 2000: accomplishment recognizrd. J Am Dent Assoc 1999;130(9):1291-98.

Montebugnoli LS, Chersoni C, Prati C, Dolci G. A between-patient disinfection method to control water line contamination and biofilm inside dental units. J Hosp Infect 2004;56(4):297-304.

Pinto TJA, Kaneko TM, Ohara MT. Controle biológico de produtos farmacêuticos, correlatos e cosméticos. $1^{\text {a }}$ ed. São Paulo: Atheneu; 2000.

Rautemaa R, Nordberg A, Wuolijoki-Saaristo K, Meurman JH. Bacteral aerosols in dental practice - a potential hospital infection problem? J Hosp Infect 2006;64(1):7681.

Rajala-Mustonen RL, Toivola PS, Heinonen-Tanski H. Effect of peracetic acid and UV irrdation on the inactivation of coliphages in wastewater. Water Sci Technol 1997;35(11-12):237-41. 
Rideout K, Tesche K, Dimich-Ward H, Kennedy SM. Considering risks to healthcare workers from glutaraldehyde alternatives in high level disinfection. J Hosp Infect 2005;59(1):4-11.

Rutala WA. APIC guideline for selection and use of disinfectants 1994, 1995 e 1996. Am J Infect Control 1996;24(4):313-42.

Rutala WA, Weber DJ. Disinfection of endoscopes: review of new chemical sterilants used for high-level disinfection. Infect Control Hosp Epidemiol 1999;20(1):69-76.

Rutala WA, Weber DJ. New disinfection and sterilization methods. Emerg Infect Dis $2001 ; 32(1): 1348-56$.

Rutala WA, Weber DJ. How to asses risk of disease transmission to patients when there is a failure to follow recommended disinfection and sterilization guidelines. Infect Control Infect Hosp Epidemiol 2007;28(2):146-55.

Sattar SA, Kibbee RJ, Tetro JA, Rook TA. Experimental evaluation of an automated endoscope reprocessor with in situ generation of peracetic acid for disinfection of semicritical devices. Infect Control Infect Hosp Epidemiol 2006;27(11):1193-99.

Schaefer ME. Infection control: Dealing with the special patient. J Calif Dent Assoc 1994;22(8):20-4.

Serruya SJ. Apresentação. In: Ministério da Saúde. Secretaria de Ciência, Tecnologia e Insumos Estratégicos Departamento de Ciência e Tecnologia. Classificação de risco dos agentes biológicos. Brasília: Editora MS; 2006. Série A. [Normas e Manuais Técnicas]. p. 7-8.

Shearer BG. Biofilm and the dental office. J Am Dent Ass 1996;127(2):181-89.

Stampi S, De Luca G, Zanetti F. Evaluation of the efficiency of peracetic acid in the disinfection of sewage effluents. J Appl Microbiol 2001;91(5):833-8.

Stampi S, De Luca G, Onorato M, Ambrogiani E, Zanetti F. Peracetic acid as an alternative wastewater disinfectant to chlorine dioxide. J Appl Microbiol 2002;93(5):725-31.

The United States Pharmacopeia: USP 29: the National Formulary: NF 24: by authority of the United States Pharmacopeial Convention, Inc., meeting at 
Washington, D.C., March 9-13, 2005 prepared by the Council of Experts and published by the Board of Trustees. Rockville: United States Pharmacopeial Convention; c2005.

Tortora GJ, Funke BR, Case CL. Microbiologia. 6. ed. Porto Alegre: Artmed; 2003.

Vizcaino-Alcaide MJ, Herruzo-Cabrera R, Fernandez-Aceñero MJ. Comparison of the disinfectant efficay of Perasafe ${ }^{\circledR}$ and $2 \%$ glutaraldehyde in vitro tests. J Hosp Infect 2003;53(2):124-28.

Wagner M, Brumelis D, Gehr R. Disinfection of wastewater by hydrogen peroxide or peracetic acid: development of procedures for measurement of residual disinfectant and application to a physicochemically treated municipal effluent. Water Environ Res 2002;74(1):33-50.

Wutzler $P$, Sauerbei A. Virucidal efficacy of a combination of $0,2 \%$ peracetic and $80 \%$ $(\mathrm{v} / \mathrm{v})$ ethanol (PAA-ethanol) as a potential hand disinfectant. J Hosp Infect 2000;46(4):304-8. 
ANEXO A Termo de Consentimento Livre e Esclarecido

Título do Estudo: Eficácia do ácido peracético na desinfecção de instrumentos contaminados.

Orientador e pesquisador: Prof. Dr. Jayro Guimarães Júnior

Examinadora: CD Gabriela Artico.

Instituição/Departamento: FOUSP - Departamento de Estomatologia

Local da coleta de dados: Clínica de Semiologia da FOUSP.

Prezado (a) Senhor (a):

Você está sendo convidado (a) a participar desta pesquisa de forma voluntária. Antes de sua participação, é muito importante que você compreenda as informações contidas neste documento. Os pesquisadores deverão responder todas as suas dúvidas antes de sua decisão em participar. Você tem o direito de desistir a qualquer momento sem nenhuma penalidade e sem perder os benefícios aos quais tenha direito.

\section{Objetivo do Estudo}

Avaliar a eficácia do ácido peracético na desinfecção de instrumentais contaminados 


\section{Procedimentos}

Sua participação nesta pesquisa será a de permitir que coletemos com instrumento apropriado (micro aplicador descartável de resina), material de sua bochecha (lado direito e esquerdo), palato duro (céu da boca) e dorso de língua. $\mathrm{O}$ método para coleta do material necessário é inócuo, não invasivo e por isso não traz nenhum risco á saúde ou desconforto e os procedimentos que serão realizados após, estarão de acordo com o protocolo e sistemática da Disciplina de Semiologia. Este método consiste em esfregar delicadamente o microaplicador de resina nestas quatro regiões de sua boca e após, colocá-lo em recipiente de transporte, para realização da pesquisa em laboratório.

\section{Benefícios}

Esta pesquisa trará mais conhecimento a respeito de agente desinfetante que não cause malefício aos pacientes, profissionais da saúde e meio ambiente.

\section{Sigilo}

As informações trazidas por você serão confidenciais e de conhecimento apenas da pesquisadora e seu orientador. Nenhuma imagem será feita ou os resultados identificados nominalmente ou divulgados.

Gabriela Artico (C. D), bem como seu orientador, Prof. Dr. Jayro Guimarães Jr. poderão ser encontrados à Avenida Prof. Lineu Prestes, 2227 - Cidade Universitária, 
ou pelo telefone 3091-7883 para o esclarecimento de qualquer dúvida ou caso o (a) senhor (a) deseje retirar seu consentimento.

Após ler estas informações e de ter minhas dúvidas suficientemente esclarecidas pelo pesquisador, concordo em participar de forma voluntária neste estudo.

São Paulo, de de

Paciente:

Documento:

Telefone:

C. D. Dra. Gabriela Artico- N USP: 5266534 
ANEXO B - Parecer do Comitê de ética em pesquisa da FOUSP

\author{
UNIVERSIDADE DE SÃO PAULO \\ FACULDADE DE ODONTOLOGIA
}

\title{
PARECER DE APROVAÇÃO \\ Protocolo 187/06
}

Com base em parecer de relator, o Comitê de Ética em Pesquisa APROVOU o protocolo de pesquisa "Eficácia do ácido peracético na desinfecção de instrumentos contaminados", de responsabilidade do Pesquisador Professor Doutor Jayro Guimarães Júnior.

Tendo em vista a legislação vigente, devem ser encaminhados a este Comitê relatórios anuais referentes ao andamento da pesquisa e ao término cópia do trabalho em "cd". Qualquer emenda do projeto original deve ser apresentada a este CEP para apreciação, de forma clara e sucinta, identificando a parte do protocolo a ser modificada e suas justificativas.

São Paulo, 05 de dezembro de 2006

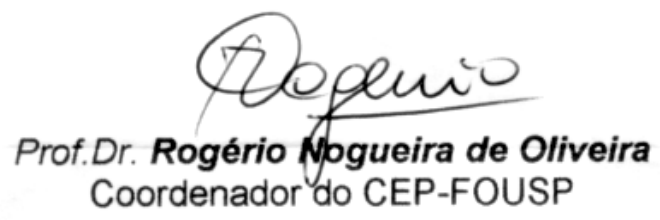


ANEXO C - Parecer do Comitê de ética em pesquisa da CFC/USP

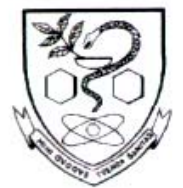

UNIVERSIDADE DE SÃO PAULO

Faculdade de Ciências Farmacêuticas Comitê de Ética em Pesquisa - CEP

$\underline{\text { Ofício CEP n }{ }^{\circ} 07 / 2007}$

São Paulo, 06 de fevereiro de 200.

IImo(a). Sr(a)

Prof Jayro Guimarães Junior

FO/FBC

Prezado(a) Senhor(a),

O Comitê de Ética em Pesquisa da FCF/USP, em reunião realizada em 05 de fevereiro de 2007, APROVOU o projeto "Eficácia do ácido peracético na desinfecção de instrumentos contaminados" (Protocolo CEP $n^{\circ} 404$ ) apresentado por Vossa Senhoria, devendo apenas ser informado a referência bibliográfica dos ensaios utilizados que serão realizados.

Lembramos que após a execução de $50 \%$ do cronograma do projeto, deverá ser apresentado um relatório parcial, de acordo com o Artigo 18 - item C, da Portaria FCF-111/97.

Atenciosamente,

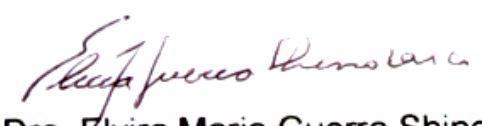

Profa. Dra. Elvira Maria Guerra Shinohara

Vice-Coordenadora do Comitê de Ética em Pesquisa

FCF/USP 